\title{
SECTION 241 AND THE FIRST AMENDMENT: AVOIDING A FALSE CONFLICT THROUGH PROPER MENS REA ANALYSIS
}

\author{
ADAM G. SAFWAT $\dagger$
}

\section{INTRODUCTION}

Although 18 U.S.C. $\S 241,{ }^{1}$ a criminal civil rights statute, receives scant recognition as a civil rights enforcement provision and is often eclipsed by its sister statute, 18 U.S.C. $\S 242,{ }^{2}$ the Justice Department and U.S. attorneys realize that section 241, which proscribes conspiracies to violate individuals' federally protected rights, is a powerful weapon in the federal civil riglits enforcement arsenal. Section 241 was designed to punish "traditional" civil rights crimes, sucli as those committed by the $\mathrm{Ku}$ Klux Klan and similar organizations that sprung up after the Civil

$\dagger$ The author is indebted to Professor Sara S. Beale and Professor William W. Van Alstyne for their invaluable advice.

1. Section 241 provides,

If two or more persons conspire to injure, oppress, threaten, or intimidate any inhabitant of any State, Territory, or District in the free exercise or enjoyment of any right or privilege secured to him by the Constitution or laws of the United States, or because of his having so exercised the same; or

If two or more persons go in disguise on the highway, or on the premises of another, with intent to prevent or hinder his free exercise or enjoyment of any right or privilege so secured-

They shall be fined not inore than $\$ 10,000$ or imprisoned not more than ten years, or both; and if death results, they shall be subject to imprisonment for any term of years or for life.

18 U.S.C. $\$ 241$ (1988).

2. Section 242 provides,

Whoever, under color of any law, statute, ordinance, regulation, or custom, willfully subjects any inhabitant of any State, Territory, or District to the deprivation of any rights, privileges, or inmunities secured or protected by the Constitution or laws of the United States, or to different puuishments, pains, or penalties, on account of such inhabitant being an alien, or by reason of his color, or race, than are prescribed for the punishment of citizens, shall be fined not more than $\$ 1,000$ or imprisoned not more than one year, or both; and if bodily injury results shall be fined under this title or imprisoned not more than ten years, or both; and if death results shall be subject to imprisonment for any term of years or for life.

18 U.S.C. \& 242 (1988). 
War, ${ }^{3}$ but the statute reaches far beyond such crimes to punish most conspiracies designed to interfere with another's exercise or enjoyment of a federally protected right. ${ }^{4}$ The statute has been used, for mstance, to prosecute local law enforcement officials who abuse their authority, ${ }^{5}$ federal executive branch officials who engage in illicit political schemes, ${ }^{6}$ and organized crime figures who conspire to prevent mcriminating witnesses from testifying against them. ${ }^{7}$

With the continued manifestation of hate crimes in America, ${ }^{8}$ section 241 is becoming an imcreasingly valuable tool for federal civil rights enforcement. Since many hate crimes involve interference, or attempted interference, with the victim's exercise of his federal rights, prosecutors can link the protected interest to a section 241 conspiracy charge. Section 241 has been used to pumish those who would deprive others of the use of public accommodations $^{9}$ or the enjoyment of their homes or property ${ }^{10}$ because of their race. Such uses of section 241 are not without their consequences, however. Because some prosecutors may be tempted to view section 241 as a catchall hate crimes statute, the statute is susceptible to abuse.

This Note argues that despite the breadth of the statute's reach, section 241 has two elements that, when properly applied, ensure that federal prosecutors will not misuse the statute. First, because section 241 is an enforcement vehicle for federal statutory and constitutional rights, prosecutors must define the predicate

3. See United States v. Price, 383 U.S. 787, 803-04 (1966).

4. See infra notes 29-38 and accompanying text.

5. See, e.g., United States v. O'Dell, 462 F.2d 224 (6th Cir. 1972).

6. See, e.g., United States v. Ehrlichman, 546 F.2d 910 (D.C. Cir. 1976), cert. denied, 429 U.S. 1120 (1977).

7. See, e.g., United States v. DiNome, 954 F.2d 839 (2d Cir.), cert. denied, 113 S. Ct. 94 (1992).

8. See Federal Bureau of Investigation, Hate Crime Statistics, 1990, at 5 (1992) (finding that the najority of states that keep data on bias crimes reported that the most common notivations were race and anti-Semitism); N.R. Kleinfield, Bias Crimes Hold Steady, but Leave Many Scars, N.Y. TimES, Jan. 27, 1992, at A1, B2 (reporting on varied incidents of bias crimes and on the increase of bias crimes against Arabs and Jews during and after the Persian Gulf War); see also Stephen Labaton, Poor Cooperation Deflates F.B.I. Report on Hate Crimes, N.Y. TIMES, Jan. 6, 1993, at A10 (discussing the release of the FBI Report on Hate Crimes).

9. See, e.g., United States v. Greer, 939 F.2d 1076, 1081-82 (5th Cir.) reh'g granted, 948 F.2d 934 (5th Cir. 1991), reinstated in part on reh'g en banc, 968 F.2d 433 (5th Cir. 1992), cert. denied, 113 S. Ct. 1390 (1993).

10. See, e.g., United States v. Worthy, 915 F.2d 1514 (11th Cir. 1990). 
right on which a section 241 charge is based. ${ }^{11}$ Second, prosecutors must show that the defendant's state of mind satisfies the statute's specific intent requirement, namely, that the defendant has a purpose to deprive another of the enjoyment of his federal right. ${ }^{12}$ These two elements are linked; to prove specific intent, one must first identify the right of which the defendant conspired to deny his victim.

A case from the U.S. Court of Appeals for the Eighth Circuit, United States v. Lee, ${ }^{13}$ demonstrates the First Amendment concerns that arise when section 241 is mproperly invoked. In Lee, the defendant burned a cross almost 400 feet away from a multi-racial apartment complex. He was convicted under section 241 of conspiring to violate the housing rights of the complex's African-American tenants. ${ }^{14}$ Although conceding that the defendant's conduct miphicated the First Amendment because cross burning is recognized as protected symbohic conduct, the Eighth Circuit affirmed his conviction..$^{15}$ An en banc court reversed the defendant's conviction and remanded for retrial in accordance with its instructions. ${ }^{16}$

In its decisions in Lee, the Eighth Circuit formulated and then resolved a conflict between section 241 and the First Amendment that it never should have addressed. The defendant should not have been convicted under section 241 ; the prosecutor did not properly define the victims' federally protected rights and failed to prove that the defendant had the specific intent to conspire to deprive his victims of their federal rights.

Part I of this Note provides an overview of the elements of an offense under section 241 and examines the statute's mens rea requirement. Unhike 18 U.S.C. $\S 242$, section 241 requires that the

11. Thus, the prosecutor cannot simply charge an individual with violating $\$ 241$; rather, the prosecutor must identify a federal interest that the defendant sought to prevent his victim from enjoying. It is the conspiracy to interfere with the exercise of the victim's federal right, foimd elsewhere in federal statutory or constitutional law, that $\S$ 241 proscribes. See Anderson v. United States, 417 U.S. 211, 223 (1974); see also infra notes $29-43$ and accompanying text (noting rights on which $\$ 241$ charges are predicated).

12. United States v. Guest, 383 U.S. 745, 760 (1966).

13. 935 F.2d 952 (8th Cir. 1991), opinion and judgment vacated as to Count I, id. at 960, rev'd and remanded, 6 F.3d 1297 (8th Cir. 1993) (en banc) (per curiam).

14. Id. at $953-54$.

15. Id. at $954-58$.

16. Lee, 6 F.3d at 1297. 
defendant conspire with the purpose of denying his victims their federally protected interests. ${ }^{17}$ Part II analyzes cases brought under section $241 .^{18}$ The discussion explores the courts' treatment of the mens rea requirement of the statute. Several cases suggest that courts are prepared to treat mens rea as a mere formahty in cases mvolving official misconduct. Part III exarmines the panel opinion's conclusion in Lee that the defendant's conduct satisfied the elements of section 241 and analyzes the First Amendment issues that Lee raises. Part III then analyzes the en banc plurality's conclusions on the constitutionality of section 241, and includes a discussion of the imphications of United States $v$. Lee for the future use of section 241 in hate crime cases.

This Note concludes that the tension between the First Amendment and section 241 is illusory and can be avoided through the proper application of the statute's mens rea element and the careful identification of the predicate right on which a section 241 charge is based. The consequences of failing to properly interpret the statute's mens rea requirement are significant and cut both ways. First, in cases involving expressive conduct, the statute inay be used too aggressively to punish constitutionally protected conduct. Second, soine courts niay react to the Lee case by entertaining arguments froin defendants that section 241 imphcates free expression, even when the evidence shows that the defendant's conduct would not receive First Amendment protection. Consequently, the punishment of perpetrators of hate crimes will be hindered if courts uimecessarily "tailor" section 241 to address misconceived First Amendment concerns.

\section{The Elements of A Section 241 OfFense}

To prove a violation of section 241 , the prosecution must show: (1) that two or more people conspired to deprive someone of a federally protected right; ${ }^{19}$ (2) that they acted with specific

17. Section 242's mens rea requirement is sometimes thought to be less demanding. See infra notes $70-74$ and accompanying text. To be charged under $\S 242$, however, the defendant must act under color of law. See supra note 2.

- 18. Because of its limited scope, this Note will focus only on $\S 241$. In cases in which purely private conduct is being prosecuted, such as racial intimidation without participation by state actors, only $\S 241$ applies because $\S 242$ requires that the defendant act under color of law. For a thorough discussion of the mens rea element of $\S 242$, see Edward F. Malone, Legacy of the Reconstruction: The Vagueness of the Criminal Civil Rights Statutes, 38 UCLA L. REV. 163 (1990).

19. See Anderson v. United States, 417 U.S. 211, 223 (1974); United States v. Guest, 
intent to deprive the individual of this right; ${ }^{20}$ and (3) that the federal right violated was clearly delineated. ${ }^{21}$ This last requirement ensures that the statute, which is broad in its reach, does not violate minimum standards of due process. ${ }^{22}$

\section{A. The Predicate Federal Right}

Section 241 does not establish substantive rights; rather, it provides criminal sanctions against those who conspire to interfere with a person's exercise of other federally guaranteed rights. Shortly after the Civil War, increasing acts of intimidation by the $\mathrm{Ku}$ Klux Klan and similar groups, intended to prevent AfricanAmericans from voting, prompted Congress to pass the Enforcement Act of 1870 (the Act), ${ }^{23}$ which included what is now section 241 and its sister statute, section $242 .^{24}$ The purpose of the Act was to enforce the newly ratified Fourteenth and Fifteenth Amendınents, ${ }^{25}$ which guaranteed to all citizens equal protection

383 U.S. $745,753-54$ (1966).

20." Anderson, 417 U.S. at 223.

21. In Screws v. United States, 325 U.S. 91 (1945), the Court held that $\$ 242$ was not void for vagueness because its violation requires, at a mininum, the reckless disregard for a "specific and definite" constitutional right. Id. at 105. Likewise, because $\$ 241$ is also an enforcenent vehicle for other rights, it follows that these rights must be "specific and definite." See infra notes $44-48$ and accompanying text.

22. United States v. Ehrlichman, 546 F.2d 910, 921 (D.C. Cir. 1976), cert. denied, 429 U.S. 1120 (1977).

Because $\S 241$, like $\S 242$, is used to punish a broad range of conspiracies, it sonetimes reaches conduct that traditionally is regarded as within the proper domain of state law. See infra notes 132-35 and accompanying text. Several members of the U.S. Supreme Court have questioned whether $\S 241$ and $\$ 242$ violate principles of federalisin when construed broadly, even when used to punish interferences with federal rights. See Screws, 325 U.S. at 142 (Roberts, Frankfurter, and Jackson, JJ., dissenting) (arguing that $\$ 242$ should not be extended to situations in which the defendant's conduct violates state authority); see also United States v. Williams, 341 U.S. 70, 73, 82 (1951) (plurality opinion) (holding that $\$ 241$ does not reach all rights arising under the Constitution but only those arising fron a "relation" between an individual and the "substantive powers" of the federal governnent). Justice Frankfurter's plurality opinion in Williams was later overruled in United States v. Price, 383 U.S. 787, 800 (1966) (holding that $\$ 241$ protected all rights and privileges secured by federal, constitutional, or statutory law). For a discussion of Price, see infra note 37. The question of whether $\S 241$ violates principles of federalisin is, however, outside the scope of this Note.

23. Price, 383 U.S. at 804-05.

24. Section 241 was originally enacted as $\S 6$ of the Enforcement Act of 1870, $\S 6$, 16 Stat. $140,141$.

25. See Price, 383 U.S. at 801-02. The only legislator to comment on section 241 was Senator John Pool of North Carolina, who "urged that the section was needed in order to punish invasions of the newly adopted Fourteenth and Fifteenth Ainendments." Price, 
of the laws and the right to vote, respectively ${ }^{26}$ North Carolina Senator John Pool argued that the Act served the broad purpose of punishing private citizens who interfered with the rights of other private citizens by acts of violence and intimidation. ${ }^{27} \mathrm{Be}$ cause of the absence of other nore specific legislative history, the U.S. Supreme Court has determined the scope of section 241 largely froni the broader purposes of the Act and subsequent reenactnients of sections 241 and $242 .^{28}$

Although primarily designed to protect the right to vote, ${ }^{29}$ section 241 also has reached the right to have one's vote counted fairly, ${ }^{30}$ the right to be protected fron "lawless violence" while in the custody and control of a federal niarshal, ${ }^{31}$ and other rights that Congress has the constitutional power to create, such as the right to effectuate one's claim to land under the Hoinestead Acts. $^{32}$ In United States v. Classic, ${ }^{33}$ the Court extended section 241's protection of the right to vote to state primaries in federal elections. ${ }^{34}$ In the 1960 s, when Congress increased its regulation of private behavior through civil rights legislation, ${ }^{35}$ section 241 's

383 U.S. at 805 (citing CONG. GLOBE, 41st Cong., 2d Sess. 3611 (1870)) ("Remarks of Senator John Pool of North Carolina on sponsoring Sections 5, 6 and 7 of the Enforcement Act of 1870").

26. The Fourteenth Amendment provides in pertiment part,

No State shall make or enforce any law which shall abridge the privileges or immunities of citizens of the United States; nor shall any State deprive any person of life, liberty, or property, without due process of law; nor deny to any person withim its jurisdiction the equal protection of the laws.

U.S. CONST. amend. XIV, $\S 1$. The Fifteenth Amendment reads, "The right of citizens of the United States to vote shall not be denied or abridged by the United States or by any State on account of race, color, or previous condition of servitude." U.S. CoNST. amend. XV, § 1. For further background on the Enforcement Act of 1870 and subsequent judicial interpretation of the Fourteenth Amendment, see Eugene Gressman, The Unhappy History of Civil Rights Legislation, 50 MiCH. L. REV. 1323, 1334-43 (1952).

27. See Charles H. Jones, Jr., An Argument for Federal Protection Against Racially Motivated Crimes: 18 U.S.C. $\S 241$ and the Thirteenth Amendment, 21 HARV. C.R.-C.L. L. REv. 689, 718-19 (1986).

28. See Price, 383 U.S. at 803 . For an extensive discussion of the legislative history and judicial interpretation of $\S 241$ and $\S 242$, see Gressman, supra note 26.

(1884).

29. Gressman, supra note 26, at 1345; see Ex parte Yarbrough, 110 U.S. 651, 665

30. United States v. Mosley, 238 U.S. 383, 386 (1915).

31. Logan v. Umited States, 144 U.S. 263, 285 (1892).

32. United States v. Waddell, 112 U.S. 76, 78-9 (1884); see Gressman, supra note 26. at $1346-47$.

33. 313 U.S. 299, reh'g denied, 314 U.S. 707 (1941).

34. Id. at 320.

35. "Congressional power over botls private and state action ... emanates from ... 
reach was significantly broadened. Since the passage of the Civil Rights Act of 1964 and subsequent civil rights measures, prosecutors have used section 241 to enforce the rights that those statutes guarantee by punishing people who conspire to interfere with individuals' enjoyment of their rights. ${ }^{36}$

Frequently, a specific guarantee within the Bill of Rights or the Fourteenth Amendinent's Due Process and Equal Protection Clauses provides the predicate right required for a violation of section $241 .^{37}$ As imterpreted today, section 241 secures all federally guaranteed individual rights, whether derived froin the Constitution or froin federal legislation. ${ }^{38}$

If the Fourteenth Amendment provides the predicate right, state action is a necessary element of the deprivation ${ }^{39}$ because $^{-1}$

the necessary and proper clause [and] the commerce clause." Nancy S. Abramowitz, Legislating Civil Rights: The Role of Sections 241 and 242 in the Revised Criminal Code, 63 GEO. L.J. 203, 204-05 (1974) (footnotes omitted).

36. For instance, prosecutors can link $\S 241$ to 42 U.S.C. $\$ 2000 a(a)$ (1981), which protects the right to enjoy public accommodations, and to 42 U.S.C. $\$ 3631$ (a) (Supp. 1993), which guarantees the right to live in one's dwelling free from force or the threat of force on account of one's race. For a discussion of cases involving $\S 241$ as an enforceinent velicle for these rights, see infra notes 86,145 and accoinpanying text.

37. The question of whether $\S 241$ covered the Fourteenth Amendment reinained unresolved until 1966, when the U.S. Supreine Court decided United States v. Price, 383 U.S. 787, 800 (1966) ("The language of $\$ 241$ is plain and unlimited. As we have discussed, its language embraces all of the rights and privileges secured to citizens by all of the Constitution and all of the laws of the United States.").

In Price, three Mississippi law enforceinent officers and fifteen private individuals conspired to falsely arrest and then murder three African-Americans. Id. at 789-90. The victims were civil rights workers. Malone, supra note 18, at 190 . After being detained in the county jail, one officer released the victims; the officer later intercepted their automobile and took them to where the two other law enforcement officers and the fifteen other men were waiting. The men then shot and killed the civil rights workers. Price, 383 U.S. at 790. The participants were charged with conspiring to deprive their victims of life without due process of law under $\$ 241$. Id. at 796. The Court reaffirmed that the Fourteenth Amendment could not be violated without state action: "[W]e have consistently held 'The Fourteenth Amendinent protects the individual against state action, not against wrongs done by individuals."' Id. at 799 (quoting United States v. Williams, 341 U.S. 58, 92 (1951) (Douglas, J., dissenting)). Because three law enforcement officers participated in the conspiracy, the Court held that "the conspiracy [was] within the ambit of the Fourteentl Amendment." Id. Since the private individuals were acting jointly with law enforcenient officers, they were also deemed to be acting under color of law. Id. at 794-95. See infra note 43 and accounpanying text.

38. Price, 383 U.S. at 799 . However, $\S 241$ does not protect against statutory deprivations when the statutory scheme provides for exclusive noncriminal remedies. Abramowitz, supra note 35, at 213.

39. Some constitutional rights are held against both private and state actors, i.e., "against the world." They include the Thirteenth Amendinent right to be free froin invol- 
the Fourteenth Amendment, the most frequently used source of constitutional rights in section 241 charges, only applies against the states. ${ }^{40}$ Federal or state officials who conspire to deprive citizens of their constitutional rights can be punished under the statute when they act under color of law. ${ }^{41}$ A classic example of the use of section 241 in conjunction with the Fourteenth Amendment is the prosecution of police officers for racially motivated deprivations of due process. ${ }^{42}$ In limited situations, Congress also can prohibit private individuals from conspiring to interfere with the constitutional rights of others. Individuals acting jointly with state officials are presumed to have acted under color of law. ${ }^{43}$

Because section 241 protects a broad range of federal rights, it is open to charges of being void for vagueness. ${ }^{44}$ The U.S. Supreme Court addressed the question of whether section 242 violated the constitutional principle against vagueness in Screws $v$. United States. ${ }^{45}$ To remedy any potential vagueness problem, the underlying right must be "specific and definite," 46 and the government must show a defendant's specific imtent to violate this right. ${ }^{47}$ Since, like section 242 , section 241 's scope is defined by other federal rights, the same reinedy cures section 241 of any vagueness problems. ${ }^{48}$

untary servitude and the right to travel freely between states. Bray v. Alexandria Women's Health Clinic, 113 S. Ct. 753, 764 (1993).

40. Price, 383 U.S. at 799; The Civil Rights Cases, 109 U.S. 3, 11, 17 (1883).

41. Screws v. United States, 325 U.S. 91, 107-11 (1945).

42. See, e.g., id. at 92 (involving three policemen in Baker County, Georgia, who beat to death a young black man after arresting him on a warrant charging him with the theft of a tire).

43. 'To act 'under color' of law does not require that the accused be an officer of the State. It is enough that he is a willful participant in joint activity with the State or its agents." Price, 383 U.S. at 794; see also United States v. Farmer, 923 F.2d 1557 (11th Cir. 1991) (affirming the defendant's conviction under $\S 241$ for depriving an employee he suspected of theft of his due process rights by beating him in the presence of investigators in an interrogation room at the sheriff's office).

44. See United States v. Guest, 383 U.S. 745, 753-54 (1966) (rejecting vagueness challenge to $\$ 241$ ).

45. 325 U.S. 91 (1945).

46. Id. at 105. Determining whether a right is clearly delineated is an objective inquiry. Harlow v. Fitzgerald, 457 U.S. 800, 818-19 (1982).

47. Screws, 325 U.S. at 104; see Robert C. Kates, Note, May the Intent to Violate the Federal Civil Rights Statute Be Established by a Presumption?, 40 GEO. L.J. 566, 570 (1952) (discussing the specific intent requirement as it relates to the vagueness issue).

48. Guest, 383 U.S. at $753-54$ (holding that $\S 241$ 's scienter requirement keeps it from being unconstitutionally vague) (citing Screws, 325 U.S. at 104). 
One commentator has argued that the issue of what constitutes a clearly delineated right has been rarely hitigated because "the Justice Department has, with some exceptions, limited its prosecutions under sections 241 and 242 to violations of a discrete and limited set of rights"-usually Fourteenth Amendment due process rights. ${ }^{49}$ This statement, however, is not entirely accurate because prosecutors have used section 241 ' ${ }^{\prime}$ conjunction with federal statutory rights that imght not be as "clearly defined" as due process rights. ${ }^{50}$ The following discussion of section 241's mens rea requirement illustrates the importance of properly defining the predicate right: absent a clear definition of the protected interest, it is difficult, if not impossible, to formulate the correct mens rea imquiry, thereby potentially prejudicing the defendant.

\section{B. Section 241's Mens Rea Requirement}

Since section 241 is a conspiracy statute, common law principles dictate that specific intent is an element of a section 241 offense. ${ }^{51}$ Nonetheless, the U.S. Suprenie Court did not articulate a mens rea requirement for the statute until 1966, when it decided United States v. Guest. ${ }^{52}$ The defendants in Guest were indicted under section 241 for conspiring to interfere with the rights of African-Americans to travel freely to and from Georgia. ${ }^{53}$ The district court dismissed the mdictment because it did not find the right to interstate travel in the Constitution. ${ }^{54}$ The Suprene Court reversed, stating that the right to travel was firmly estabhished im the Constitution..$^{55}$ Nevertheless, the Court specified that

49. Malone, supra note 18 , at 168 n.21.

50. See, e.g., supra note 36 .

51. See Wayne R. LaFave \& Austin W. Scott, JR., Criminal Law § 6.4(e) (2d ed. 1986).

52. 383 U.S. 745 (1966).

53. Id. at 757. The defendants were also charged under $\S 241$ with conspiring to deprive African-Americans of their rights to use the public facilities near-Athens, Georgia. Id. at 749. The district court dismissed the indictment, finding that $\S 241$ did not embrace the Equal Protection Clause of the Fourteenth Amendment. Id. at 748. The Supreme Court reversed, citing its opinion in United States v. Price, 383 U.S. 787 (1966), announced the same day. Guest, 383 U.S. at 753. For a discussion of Price, see supra note 37.

54. Guest, 383 U.S. at 757,759 n.16.

55. Id. at 757-59. The right to travel is one of the few constitutional rights that can be infringed without state action. See supra note 39. 
on remand, the prosecutor was required to prove that the defendant acted with the specific intent to interfere with this right.

Thus, for example, a conspiracy to rob an interstate traveler would not, of itself, violate section 241. But if the predominant purpose of the conspiracy is to impede or prevent the exercise of the right of interstate travel, or to oppress a person because of his exercise of that right, then, whether or not motivated by racial discrimination, the conspiracy becones a proper object of [section 241]. ${ }^{56}$

Guest estabhished that to be guilty under section 241 , the defendant inust act with the specific purpose to deprive someone of a federally guaranteed right, not merely with the purpose to commit the act that causes the deprivation. ${ }^{57}$

Since Guest, however, solne courts have diluted the specific intent requirement of section 241. In United States v. Ehrlichman, ${ }^{58}$ the U.S. Court of Appeals for the District of Columbia Circuit defined the specific intent required as "the purpose ... to commit acts which deprive a citizen of interests in fact protected by clearly defined constitutional rights." ${ }^{59}$ Under this definition, the defendant must have only the purpose to conspire to commit an act causing a deprivation of a federally protected interest, rather than the purpose to conspire to cause a deprivation of a federally protected interest.

The Model Penal Code (the MPC) shows that this difference is not as subtle as it nay seem at first blush. The MPC distinguishes between three "components" of the actus reus of each offense: conduct, result, and attendant circumstance. ${ }^{60}$ The MPC defines the mens rea of purpose with respect to each element: "A person acts purposely with respect to a material element of an offense when: (i) if the element involves the nature of his conduct or a result thereof, it is his conscious object to engage in conduct

56. Guest, 383 U.S. 'at 760.

57. The prosecutor does not have to show that the defendant had a specific statutory or constitutional right in mind when he acted: the defendant need not be "thinking in constitutional terms." Screws v. United States, 325 U.S. 91, 106 (1945).

58. 546 F.2d 910 (D.C. Cir. 1976), cert. denied, 429 U.S. 1120 (1977). For a discussion of the facts of the case, see infra note 93 and accompanying text. The Ehrlichman case is one of the few cases that offers a lengthy discussion of $\S 241$ 's scienter requireinent.

59. Ehrlichman, 546 F.2d at 922 (emphasis added).

60. Peter W. Low et al., Criminal Law 233 (2d ed. 1986). 
of that nature or to cause such a result." ${ }^{\text {"61 }}$ The Supreme Court's holding in Guest indicates that section 241 is a result-oriented crime-the defendant must act purposely with respect to the resulting deprivation of the federal right. ${ }^{62}$ Because section 241 is a conspiracy statute, the actor must make an agreement to achieve a certain result. The Ehrlichman court, however, failed to see this distinction; it focused on the actor's mens rea vis-à-vis his planned conduct rather than his ultimate goal. ${ }^{63}$

Applying the MPC's analysis helps clarify the mens rea component of section 241. For example, a group of people could conspire to rob everyone travelling on a certain highway. The ultimate purpose of the conspiracy is to unlawfully deprive people of their personal property and to exercise control over that property. Alternatively, this same group could conspire to commit the same act, but with the ultimate purpose of discouraging people from using that particular highway. In both conspiracies, the planned conduct is identical; it is the target offense that distinguishes them. Guest requires that the prosecutor demonstrate that the ultimate objective of the conspirators was to deprive individuals of federally protected rights. $^{64}$

The Ehrlichman court reached its conclusion about section 241 's specific intent requirement by misconstruing the Supreme

61. MOdel Penal CODE $\S 2.02$ (1962) (emphasis added); see LOW ET AL., supra note 60 , at 235 .

62. See United States v. Guest, 383 U.S. 745, 760 (1966).

63. See Ehrlichman, 546 F.2d at 922 . A complicating factor arises in that the common law definition of specific intent could embrace what the Model Penal Code describes as either "purpose" or "knowledge." In other words, the defendant intends a result if it is her conscious object (i.e., purpose) to cause the result or if she knows that it will occur. JoshuA DRESSLER, UNDERSTANDING CRIMINAL LAW \& 29.05[B] (1987). In the latter case, a defendant may not have a conscious object to achieve a result but may kuow that by aiding her co-conspirators, the result will occur. The problem remains unresolved in the common law. Id. Nonetheless, the Supreme Court's choice of language in Guest strongly suggests that the defendant nust act with the purpose of achieving the resulting deprivation.

64. The poimt is nicely illustrated below:

It follows from the specific-intent nature of conspiracy that the mens rea required for guilt of conspiracy nust at times be greater (i.e., more culpable) than is required for commission of the object of the conspiracy. For example, if $D 1$ and $D 2$ agree to detonate a bomb in an occupied structure and the resulting explosion kills the occupants, they could be convicted of nurder on the basis that the killings, although perhaps unintentional, were recklessly caused. They could not be convicted of conspiracy to commit nurder, however, if their objective was to destroy the building rather than to kill someone.

DRESSLER, supra note 63, § 29.05[A] (emphasis added). 
Court's interpretation of section 241 in Anderson $v$. United States. ${ }^{65}$ In Anderson, the defendants were convicted of casting false votes in an election encompassing federal, state, and local offices. The defendants argued that since their primary purpose was to influence a local election, the prosecution could not estabhish an intent to interfere with federal voting rights. The Court dismissed this argument, stating that regardless of whether the conspiracy to interfere with a federal election was primary or secondary, if the defendants intended to violate federal law, section 241's mens rea component was satisfied. The Court stated that

[t]he specific intent required under $\S 241$ is not the intent to change the outcome of a federal election, but rather the intent to have false votes cast and thereby to injure the right of all voters in a federal election to express their choice of a candidate and to have their expressions of choice given full value and effect, without being diluted or distorted by the casting of fraudulent ballots. ${ }^{66}$

By drawing a distinction between the intent to influence an election and the intent to cast false votes, the Court merely defined the deprivation differently. According to the Court, when the false votes were cast, a constitutional injury occurred; it was not necessary to prove that the defendants' acts influenced the results of the federal election. By conspiring to cast false votes, the defendants simultaneously conspired to deprive voters of their constitutional rights.

The Ehrlichman court's misinterpretation of Anderson's language caused it to characterize the mens rea requirement of section 241 as less than what the statute actually requires. The court construed Anderson to mean that the purpose to coinınit an act that causes a constitutional deprivation meets section 241's mens rea standard. The court's analysis of Anderson was fiawed. First, the defendants in Anderson did not cast any false votes-i.e., committed the actus reus of the target offense-but coerced and bribed others to do so. ${ }^{67}$ Second, unlike many constitutional deprivations, the act of casting false votes is a per se violation of the constitutional rights of other citizens. If the defendants had the purpose to

65. 417 U.S. 211 (1974).

66. Id. at 226.

67. Id. at 214 . 
cast false votes, they also had the intent to deprive someone of the right to have his ballot counted fairly. In other cases, such as those involving interstate travel, however, a purpose to interfere with a highway traveler does not automatically translate into a purpose to cause a constitutional deprivation. ${ }^{68}$ Similarly, the intent of an arresting officer to use excessive force on an arrestee does not necessarily translate into the intent to deprive the arrestee of his Fourth Amendment rights. ${ }^{69}$

Another source of confusion in the Ehrlichman decision was the Guest Court's rehance on the holding in Screws that because section 242 contained a specific intent component, section 241 also required proof of specific intent. ${ }^{70}$ The Screws decision is noted for its ambiguity. ${ }^{71}$ In Screws, Justice Douglas found that the mens rea term in section 242, "willfully," meant acting "in open defiance or reckless disregard of a constitutional requirement."72 Later in the opimion, however, Justice Douglas defined "willfully" as having "the purpose to deprive the prisoner of a constitutional right." ${ }^{73}$ Federal courts have since agonized over whether the prosecution must show that the defendant acted either with the purpose to deprive the individual of a federal right or with recklessness toward the consequences of acts he knowingly committed. ${ }^{74}$ Nevertheless, despite the Guest Court's rehance on Screws,

68. United States v. Guest, 383 U.S. 745, 760 (1966).

69. For example, there may be circumstances during an arrest when the officer deliberately intends to use force to protect himself. See Graham v. Connor, 490 U.S. 386, 395 (1989) (holding "that all claims that law enforcement officers have used excessive force-deadly or not-in the course of arrest, investigatory stop, or other 'seizure' of a free citizen slould be analyzed under the Fourth Amendment and its 'reasonableness' standard").

70. Guest, 383 U.S. at 760 (citing Screws v. United States, 325 U.S. 91, 106-07 (1945)); cf. United States v. Fricke, 684 F.2d 1126, 1128 (5th Cir. 1982), cert. denied, 460 U.S. 1011 (1983) (approving same jury instructions on specific intent for $\$ 241$ and $\$ 242$, although the judge's instructions defined mens rea as purpose to commit the actus reus, thus lowering the mens rea required under $\$ 241$ ).

71. See, e.g., Malone, supra note 18 , at 168.

72. Screws, 325 U.S. at 105.

73. Id. at 107.

74. See, e.g., United States v. Kerley, 643 F.2d 299 (5th Cir. 1981) (requiring the jury to find that the defendant had the "purpose" to deprive the victim of a right under $\S$ 242). But see United States v. Messerlian, 832 F.2d 778 (3d Cir. 1987), cert. denied, 485 U.S. 988 (1988) (articulating a recklessness mens rea requirenient as sufficient to support a $\$ 242$ conviction).

Comparisons of $\S 241$ and $\S 242$ 's mens rea requirenents are suspect because $\S 241$ is a conspiracy statute, whereas $\S 242$ is not. Here, too, the Model Penal Code's frane- 
it specifically held that to be convicted under section 241 , a defendant must have evidenced a purpose to commit the target offense of the conspiracy.

In Bray v. Alexandria Women's Health Clinic, ${ }^{75}$ the Supreme Court reaffirmed the Guest Court's definition of section 241's specific intent standard. ${ }^{76}$ In Bray, the Court considered the meaning of the mens rea element in 42 U.S.C. $\S 1985$, which requires a person to act "for the purpose of depriving" any person of equal protection or privileges under the laws. ${ }^{77}$ Section 1985 is the civil counterpart of section 241, providing for damages resulting from conspiracies to violate civil rights. Relying on the Guest Court's interpretation of section 241's scienter requirement, Justice Scalia wrote that "the 'intent to deprive of a right' requirement [of section 1985(3)] demands that the defendant do more than merely be aware of a deprivation of right that he causes, and more than merely accept it; he must act at least in part for the very purpose of producing it." 78

\section{Diluting Section 241's MENS REA REQUiREMENT}

As a policy matter, interpreting section 241's scienter requirement in the manner that the Ehrlichman court suggested appears to facilitate the conviction of persons who conspire to deprive individuals of their civil rights. ${ }^{79}$ This argument is specious. As the cases discussed below illustrate, when section 241 is properly applied-i.e., when the mens rea required by Guest is shown-the defendants' actions exhibit an intent to cause a deprivation of a protected interest. By contrast, when the statute's mens rea element is not satisfied, the Ehrlichman interpretation impermissibly

work is helpful. See LOW ET AL, supra note 60, at 233-35. Section 241's actus retus component has a conduct element (the agreement) that in effect subsumes the result component (to achieve the target offense); because a conspiracy only requires proof of an agreement, a resulting offense need not be shown. On the other hand, $\S 242$ 's actus reus component has both a conduct element ("willfully subjects") and a result element ("to the deprivation of any rights"). Although courts have required a showing of purpose to. commit the conduct (e.g., purpose to assault the victim), they have waffled on whether the mens rea required to establish the result element of the actus reus must be purpose or can be satisfled with a showing of recklessness with respect to the ensuing deprivation.

75. 113 S. Ct. 753 (1993).

76. Id. at 762 .

77. 42 U.S.C. $\S 1985(3)$ (1988).

78. Bray, 113 S. Ct. at 763.

79. Cf. Jones, supra note 27. 
broadens the scope of the statute to capture conduct that Congress either did not seek to penalize or is constitutionally prohibited from proscribing. ${ }^{80}$

\section{A. The Appropriate Use of Section 241 in Traditional and Non- Traditional Civil Rights Conspiracies}

Federal prosecutors frequently employ section 241 to penalize people who detiberately conspire to deprive others of their civil rights. ${ }^{81}$ For mstance, in United States v. Haynes, ${ }^{82}$ the Jefferson

80. One commentator has proposed a two-tiered mens rea inquiry to resolve vagueness and federalism concerns surrounding $\S 241$ and $\S 242$. At the first tier, the prosecutor must show the "parallel" state law crime, such as assault; at the second tier, the prosecutor must show either a bias-motivated crime (e.g., a crime directed against someone because of her race), a "rights interference" crime (e.g., interfering with the right of a federal witness to testify), or an "official crime" (e.g., police misconduct). Proof of the second tier is what transforms the state law crime into a federal civil rights offense. Frederick M. Lawrence, Civil Rights and Criminal Wrongs: The Mens Rea of Federal Civil Rights Crimes, 67 TUL. L. REv. 2113, 2200-01 (1993).

The utility of this conceptual model is questionable. First, the statutes already have their own two-tiered inquiry that follows from the language Congress used to draft them: the government must first identify the protected right and then prove that the defendant had the specific intent to deprive an individual of that right. Since the mens rea inquiry revolves around the underlying right, proof of the specific intent to deprive the victim of his right ensures that the defendant will not be convicted for conspiring to commit an ordinary state crime. Admittedly, courts have failed to require this level of mens rea in $\$$ 242 offenses because of the ambiguity over the mens rea required vis-a-vis the result element of the actus reus component. See, e.g., supra. note 74. The proposed two tiered analysis does not eliminate this problem; indeed, Lawrence's own example with respect to the different mens rea possibilities for someone who assaults a federal witness provides a nice illustration of this ambiguity, one which he fails to resolve. See Lawrence, supra, at 2213-25. In addition, the two-tiered analysis with respect to $\S 241$ is redundant. Because the statute is a conspiracy statute, the prosecutor must show only one actus reus element-conduct (i.e., agreement)-and that this agreement was fornulated with the purpose to deprive someone of his federal rights. If the conspiracy involves parallel state law crimes, like assault, these intended crimes serve as evidence of the conspiracy. Moreover, neither the courts nor Congress has suggested anything to lend support to the proposed two-tiered analysis; to ask the courts to follow such an analysis is to ask them to reinvent the statute. Finally, the two-tiered analysis is not compelled by necessity. Although the Lawrence commendably seeks to find a solution for the vagueness problein in $\S 241$ and $\S 242$, the statutes have their own solution-proof of specific intent to deprive an individual of his protected rights. The issue of vagueness cannot be avoided entirely because $\S 241$ and $\S 242$ are broad in their reach. As long as the statutes are construed to protect a broad category of federal statutory and constitutional rights, vagueness concerns will persist. 1993).

81. Norman abrams \& Sara S. Beale, Federal Criminal law 581 (2d ed.

82. Nos. 91-5979, 91-6076, 1992 WL 296782 (6th Cir. Oct. 15, 1992). 
County Republican Party sponsored a voter registration booth at a county fair in Kentucky. The defendant was a political director of the Republican Party and was part of a sclieme to witllinold from election officials the voter registration cards of persons indicating Democratic Party affiliation. Slie was convicted under section 241 for conspiring to deprive registrants of their constitutional rights to vote. Because slie conspired to change the outcome of a federal election, the defendant's purpose clearly was to cause a constitutional deprivation. ${ }^{83}$

United States v. Greer ${ }^{84}$ involved two conspiracy charges under section 241. In that case, the defendants belonged to a group of white supremacists, the Confederate Hammerskins, who had agreed among themselves to "patrol" Robert E. Lee Park in Dallas. The defendants "chased, beat, and assaulted any nonwhites they found" in the park after dark. ${ }^{85}$ Under the first charge, the defendants were convicted for conspiring to interfere by force or threat of force witll and to intimidate African-Americans and Hispanics in the "free exercise of their constitutional rights under 42 U.S.C. $\& 2000$ a to use a public park." ${ }^{86}$ The second conspiracy charge arose froin the defendants' plan to mark the fiftieth anniversary of Kristallnacht ${ }^{87}$ by vandalizing Jewislı businesses. On November 9, 1988, two groups of Hammerskins set out to vandalize Jewish businesses, but one group abandoned the plan. Police stopped the other group and saw that their pickup truck contained baseball bats, concrete blocks, spray paint, a steel rod, and a Nazi flag. ${ }^{88}$ The defendants were charged witl conspiring to interfere with the rights of all Jews to hold property, as guaranteed under 42 U.S.C. \& $1982 .^{89}$ For each section 241 count, there was convincing evidence that the defendants acted with the purpose to

83. Id. at $* 1-* 2$.

84. 939 F.2d 1076 (5th Cir.), reh'g granted, 948 F.2d 934 (5th Cir. 1991), reinstated in part on reh'g en banc, 968 F.2d 433 (5th Cir. 1992), cert. denied, 113 S. Ct. 1390 (1993).

85. Id. at 1082 .

86. Id. at 1081.

87. "Kristallnacht" (the night of broken glass) commemorates the night of November 9, 1938, when "the Nazis vandalized Jewish businesses throughout Germany by, among other things, breaking windows." Id. at 1083 n.7.

88. Id. at 1083.

89. Id. at 1081. The defendants argued that they did not conspire to deprive Jews of their rights to hold property. The court dismissed this argument, noting that $\S 1982$ was construed to include the right to use property as well as to own it. Id. at 1091. 
conspire to threaten and intimidate citizens in the enjoyment of their rights. ${ }^{90}$

Since the 1970s, the U.S. Justice Departinent has expanded its use of section 241 to prosecute offenses not involving racially motivated acts of violence. ${ }^{91}$ United States $v$. Ehrlichman ${ }^{92}$ is a famous example of the nontraditional, but proper, use of section 241. In that case, John Ehrlichman, one of President Nixon's White House aides, was convicted of conspiring to violate the Fourth Amendment rights of Dr. Louis Fielding, whose office was broken into in connection with the Pentagon Papers affair. ${ }^{93}$ The U.S. Court of Appeals for the District of Columbia Circuit found that Ehrhichinan's approval of the plan was sufficient to make him a co-conspirator. ${ }^{94}$

In addition, prosecutors have found section 241 to be a convenient tool for convictmg organized crime figures who have killed potentially adverse witnesses..$^{95}$ In United States $v$. Dinome,$^{96}$ two members of an organized crime family were convicted of conspiring to deprive their victims of the right to serve as witnesses, although the government had not asked the victims to testify against the defendants. ${ }^{97}$ In Dinome, the victims exported used American cars to Kuwait. The defendants exported stolen cars. When one of the victims became suspicious of the defendants' activity, he noted vehicle identification numbers of the defendants' cars, and one of the defendants observed him doing so. To pre-

90. Evidence of prior acts of vandahism supported the prosecutor's case against the Hammerskins. In August 1988, the group had spray painted swastikas and anti-Semitic slogans on the walls of a synagogue. In October 1988, they again defaced the walls of the synagogue and an adjacent community center. They also shot at the windows of the synagogue. Id. at 1082-83.

91. See ABRAMS \& BEALE, supra note 81 , at 581.

92. 546 F.2d 910 (D.C. Cir. 1976), cert. denied, 429 U.S. 1120 (1977).

93. Dr. Fielding was Daniel Ellsberg's psychiatrist. Ellsberg had leaked documents containing information about the U.S. war effort in Vietnam to the press. These documents later became known as the "Pentagon Papers." Nixon's aides hoped to find something damaging about Ellsberg in Dr. Fielding's files. Id. at 915 n.6.

94. Although the court's mens rea analysis was incorrect, see supra notes 58-69 and accompanying text, its conclusion that Ehrlichman violated $\S 241$ was correct; there was enough evidence to show that Ehrlichman conspired to deprive Dr. Ellsberg of his Fourth Amendinent rights. See Ehrlichman, 546 F.2d at 915 \& n.6.

95. See, e.g., United States v. Smith, 623 F.2d 627 (9th Cir. 1980); United States v. Pacelli, 491 F.2d 1108 (2d Cir.), cert. denied 419 U.S. 826 (1974); United States v. Bufalino, 518 F. Supp. 1190 (S.D.N.Y. 1981).

96. 954 F.2d 839 (2d Cir.), cert. denied 113 S. Ct. 94 (1992).

97. Id. at 846 . 
vent the victims from becoming possible witnesses against them, the defendants lured the victims to a garage in Brooklyn and murdered them..$^{98}$ The U.S. Court of Appeals for the Second Circuit found that the requisite underlying federal right, namely, the right to testify as a witness in a federal proceeding, was present. According to the court, the right to be a federal witness "attaches at the time such a person is possessed of evidence sufficient to create the potential of becoming a federal witness." 99 Since the motivating factor behind the murders was the suppression of the victim's potential testimony, the defendants acted with the purpose to "conspire to injure, oppress, threaten, or intimidate"100 the victims in the possible exercise of their rights to testify.

Section 241 also has been used to punish law enforcement personnel for various forms of corrupt or illicit conduct that is unrelated to racial discrimination but still constitutes a deprivation of civil rights. For instance, in United States $v$. O'Dell, ${ }^{101}$ seven Tennessee law enforcement officials were charged under section 241 after they arrested people for drunk driving as they left a bar, ${ }^{102}$ jailed them, and told them that they could either pay "bail" immediately or be sentenced to a year of road work. ${ }^{103}$ The trial judge instructed the jury that they inust find that the defendants conspired to violate Tennessee law, rather than federal law. The U.S. Court of Appeals for the Sixth Circuit remanded the case, specifying that the jury must find that the defendants conspired to deprive the arrestees of their rights under the Due Process Clause of the Fourteenth Amendment, in particular, the right to a fair trial. ${ }^{104}$ The court correctly observed that there was sufficient evidence for the jury to find that the defendants had conspired with the purpose of interfering with the arrestees' federal due process rights. ${ }^{105}$

98. Id. at 845 .

99. Id. at 846 (citing United States v. Harvey, 526 F.2d 529, 535 n.6 (2d Cir. 1975), cert. denied, 424 U.S. 956 (1976)).

100. 18 U.S.C. $\& 241$ (1988).

101. 462 F.2d 224 (6th Cir. 1972).

102. "The indictment did not allege that the arrests were made without probable cause." Id. at 226 n.1a. Thus, the officers were originally acting within the scope of their duty, bringing their later actions under color of law.

103. O'Dell, 462 F.2d at 226.

104. Id. at 231 .

105. Id. at 233 . 


\section{B. Improperly Defining the Predicate Right}

Inquiry into a defendant's mens rea is not possible without first defining the predicate right because under section 241, the defendant must have the intent to commit the target offense implied by this right. The failure to properly define the predicate right correspondingly inpairs the subsequent mens rea analysis. This impairment is most obvious in cases in which the charged offense is a conspiracy to deprive a victim of his constitutional rights. By expanding the concept of state action, courts have characterized ordinary crimes as constitutional deprivations. ${ }^{106}$ This expansive concept of state action, in turn, enables courts to characterize the defendant's intent to commit the criminal acts as the intent to deprive his victim of his constitutional rights. ${ }^{107} \mathrm{Al}$ though the following cases concern state actors, courts also can inanipulate the predicate right and, consequently, the defendant's mens rea in cases involving private actors, as demonstrated in United States $v$. Lee. ${ }^{108}$ The only difference is that when a private actor is the defendant, the predicate right is usually a statutory right, which can be infringed without state action, instead of a constitutional right.

United States. v. Robinson provides an egregious exainple of a court's failure to properly isolate the predicate right. ${ }^{109}$ In that case, two Chicago police officers were charged with violating section 241 after accepting two "hit contracts" to raise money to finance a bank robbery scheme. ${ }^{110}$ In attempting to kill one of the targeted individuals while he was driving on an expressway, the officers shot and killed a passenger instead. ${ }^{111}$ Officer Robinson separately carried out another "hit" by handcuffing his victim, telling him that he had a warrant for his arrest, driving him to Indiana, and killing him by the side of the road. ${ }^{112}$ Robinson was convicted under section 241 for conspiring "to deprive citizens of their rights to life, liberty, and property without due process of law." "113

106. See infra notes $\mathbf{1 3 2 - 3 5}$ and accompanying text.

107. Id.

108. 935 F.2d 952 (8th Cir. 1991); see supra notes 13-16 and accompanying text.

109. 503 F.2d 208 (7th Cir. 1974), cert. denied, 420 U.S. 949 (1975).

110. Id. at 210 .

111. Id. at 211.

112. Id. at 212 .

113. Id. at 210. In addition, Robinson was convicted under $\S 242$ for depriving the 
Robinson's conviction under section 241 was an improper use of the statute. The necessary finding that Robinson acted under color of state law underlies his conviction under section $241 . .^{114}$ By characterizing Robinson's crimes as occurring under color of law, it was possible to charge him with conspiring to deprive his victims of their civil rights. In reality, however, Robinson's scheme was a private operation, unsanctioned by the state. ${ }^{115}$ If the court had treated Robinson as a private individual, his actions would have demonstrated a purpose to conspire to inurder people, not to deprive thein of their due process rights. ${ }^{116}$

United States v. Tarpley provides another example of a court's willingness to find a section 241 violation even when the predicate right is not clearly defined. ${ }^{117}$ This case recounts the absurd tale of a husband whose revenge on his wife's lover was of constitutional dimensions because the husband was also a deputy in the sheriff's office. Deputy William Tarpley had his wife lure her former lover, Kerry Lee Vestal, into the Tarpley residence. Once there, Tarpley tackled Vestal and struck him in the head with a lead-laden glove. He put his service pistol in Vestal's mouth and told him that he was a police sergeant and could kill Vestal because of his position. Tarpley had his wife call Deputy Pena from the sheriff's office, whom Tarpley had informed of his plan. Pena told Vestal that Tarpley had shot other people. Tarpley warned Vestal not to report the incident and threatened to kill him if he did. When Vestal drove away, Pena and Tarpley pursued him.

victims of their "constitutional rights and protections." Id.

114. The fact that Robinson was a state officer was essential to the holding that he deprived his victims of their lives without due process. If Robinson were not an officer, substantial prosecutorial creativity would have been required to structure the $\S 241$ charge differently. Robinson could have been charged with conspiring to interfere with his first victim's right to interstate travel since the killing occurred on the freeway. According to United States v. Guest, 383 U.S. 745 (1966), however, Robinson would not have had the mens rea necessary for a successful conviction under $\S 241$ because his purpose would not have been to interfere with his victim's constitutional right to travel between states. See Robinson, 503 F.2d at 760 .

115. Malone, supra note 18 , at 205 n.163.

116. "Even if Robinson had been acting under color of law, his intent was not to deprive his victims of their lives, liberty or property without due process of law. Robinson's [intent] . . . was [to] commit] murder for hire." Id. at 204 (footnote omitted). This stateinent of law does not suggest that $\S 241$ or $\S 242$ requires the defendant to think in constitutional terms (i.e., I intend to deprive hin of this right), see supra note 57; rather, it is to point out that the state action necessary to transform Robinson's conspiracy into a civil rights crime was lacking. See infra notes 122-31 and accompanying text.

117. 945 F.2d 806 (5th Cir. 1991), cert. denied, 112 S. Ct. 1960 (1992). 
Pena asked another officer to join the chase, and the two police cars followed Vestal's car to the outskirts of the town. Tarpley was successfully convicted of conspiring to deprive Vestal of his constitutional rights. ${ }^{118}$

Although Judge Higginbotham's opinion in Tarpley does not identify the specific right with which Tarpley conspired to interfere, the nature of the deprivation indicates that Tarpley was charged with conspiring to deprive Vestal of his Fourteenth Amendment due process rights. ${ }^{119}$ Tarpley's purpose, however, was to give his wife's lover a good beating, not to deprive him of his due process rights. The only reason section 241 could be imvoked in this case was because of Tarpley's status as a law enforcement officer. ${ }^{120}$

118. Id. at 807-08.

119. An excellent way for courts to avoid the mens rea question is to phrase the charge broadly as a conspiracy to deprive an individual of his substantive due process rights, rather than to identify specifically which right is being violated. Iu the Tarpley case, the conspiracy could have been to deprive the victim of either his Fourth or Fifth Amendment rights, or both. The mens rea analysis often hinges on the substantive right in question. See supra note 69 and accompanying text.

120. Evidence possibly supporting the court's finding that Tarpley acted under color of law was the fact that another police car responded to Pena's call for help and joined Pena and Tarpley in chasing Vestal out of town. Tarpley, 945 F.2d at 808. However, even the fact that Pena joined Tarpley in his home does not show that Tarpley was acting under color of law as that term was defined in United States v. Screws, 325 U.S. 91, 107-11 (1944), because Pena was acting im his capacity as a friend of Tarpley's, rather than as a fellow officer. See infra notes 122-31 and accompanying text. Both men were acting completely outside the scope of their legitimate authority.

Moreover, the Tarpley court's citation to other cases of the U.S. Court of Appeals for the Fifth Circuit to support its finding that the defendant acted under color of law is disingenuous. The court cited Delcambre v. Delcambre, 635 F.2d 407 (5th Cir. 1981) (per curiam), for the proposition that a defendant's duty status is not dispositive of the color of law question. Tarpley, 945 F.2d at 809 (citing Delacambre, 635 F.2d at 408). Delacambre, however, held that an on-duty police chief's altercation with his sister-in-law did not constitute an action under color of law for purposes of civil rehef under 42 U.S.C. § 1983. Delacambre, 635 F.2d at 408 . The Tarpley court also cited Brown v. Miller, 631 F.2d 408 (5th Cir. 1980), for the proposition that Screws held that "individuals pursuing private ains and not acting by virtue of state authority are not acting under color of law purely because they are state officers." Tarpley, 945 F.2d at 809 (citing Brown, 945 F.2d at 411). Although this is correct, the dispositive questiou is whether state authority nuade the defendant's conduct possible. In Brown, the court held that the defendant mayor's theft of a pohice chief's paychecks constituted action under color of law for purposes of a $\S 1983$ action because the defendant had access to the plaintiff's paychecks "solely" by virtue of his position as mayor. Brown, 631 F.2d at 411. The Tarpley court would extend this rationale to mean that any time an officer uses his gun, even for completely personal purposes, he has acted under color of law. Private individuals, however, have access to guus; the crime in Tarpley also could have been executed by 
In Robinson and Tarpley, the courts made the necessary determination that the defendants had acted under color of law because private actors are unable to conspire to deprive individuals of their Fourteenth Amendment rights. ${ }^{121}$ However, a careful readimg of the U.S. Supreme Court's definition of "under color of law" in Screws v. United States ${ }^{122}$ reveals that neither Robinson's nor Tarpley's actions quahify as such. In Screws, the Court stated,

The fact that a prisoner is assaulted, injured, or even murdered by state officials does not necessarily mean that he is deprived of any right protected or secured by the Constitution or laws of the Umited States . . . . Congress ... did not undertake to make all torts of state officials federal crimes. It brought within [section 242] only specified acts done "under color" of law ....

....

... It is clear that under "color" of law means under "pretense" of law. Thus acts of officers in the ambit of their personal pursuits are plainly excluded. ${ }^{123}$

Neither Robinson nor Tarpley acted pursuant to his official duties; furthermore, the officers' actions had no basis in official state policy. ${ }^{124}$ Their actions, in short, fell within the "ambit of their personal pursuits." 125

In Monroe v. Pape, ${ }^{126}$ the Supreme Court reaffirmed the meaning of "under color of law" as that term was used both in Screws and in United States v. Classic: 127 "Misuse of power, possessed by virtue of state law and made possible only because the wrongdoer is clothed with the authority of state law, is action taken 'under color of' state law." 128 This language suggests that the central test to determine if an action is taken under color of law is whether the conduct would have been possible if the defendant had not possessed the power incidental to his status as a

private individuals.

121. See Bray v. Alexandria Wounen's Health Clinic, 113 S. Ct. 753, 764 (1993).

122. 325 U.S. 91,108 (1945).

123. Id. at 108-09, 111 (citations omitted) (emphasis added).

124. This observation does not mean that if an officer exceeds his authority, he cannot be said to act under color of law. To the contrary, "[a]cts of officers who undertake to perform their official duties are included whether they hew to the line of their authority or overstep it." Id. at 111 (emphasis added).

125. Id.

126. 365 U.S. 167 (1961).

127. 313 U.S. 299 (1941).

128. Monroe, 365 U.S. at 184 (quoting Classic, 313 U.S. at 326). 
state official. ${ }^{129}$ The Court suggested a similar test in Home Telephone \& Telegraph Co. v. City of Los Angeles. ${ }^{130}$ In that case, the Court concluded that state action could be found when "the wrong itself is rendered possible or is efficiently aided by the state authority lodged in the wrongdoer." 131 Under either test, the convictions of Robinson and Tarpley are suspect because private actors could have inflicted the same injuries on their victims without being subject to punishment under section 241 .

As these two cases denıonstrate, sonie lower courts are quick to find the necessary state action to sustain a conviction for conduct that traditionally falls within the states' penal authority. ${ }^{132}$ Moreover, federal courts have interpreted the term "under color of law" broadly since Monroe. ${ }^{133}$ Whenever a law enforcenient officer, even if he is off-duty, displays a badge or a gun or causes a false arrest, a court will likely conclude that he acted under color of law. ${ }^{134}$ If these factors are determinative, then both Robinison and Tarpley were acting under color of law. However, although the Robinson and Tarpley courts' understanding of "under color of law" is ni harmony with that of most federal courts today, it is

129. See, e.g., United States v. O'Dell, 462 F.2d 224, 229 (6th Cir. 1972) (officers extorting false "bail" money fron arrestees by virtue of their authority); United States v. McClean, 528 F.2d 1250, 1258 (2d Cir. 1976) (upholding convictions of members of the Special Investigations Unit of New York City's police department under $\$ 242$ who, when given official information about persons suspected of dealing in narcotics and possessing large ainounts of cash, would "close in on the quarry" and take the cash, using the force and weapons available to them by virtue of their position). In $\mathrm{McClean}$, the judge deleted the $\S 241$ charge to avoid confusing the jury. Id. at 1254 .

130. 227 U.S. 278, 287 (1913).

I31. Id. at 287; see also William W. Van Alstyne \& Kenneth L. Karst, State Action, 14 STAN. L. REV. 3, 10-11 (1961) (concluding that "in the absence of sone conduct by a state official which makes plausible an outsider's assumption that the actor has in fact been authorized to act for the state in some manner, the actor's conduct will not satisfy the state action requirement").

132. Cf. United States v. Delerme, 457 F.2d 156 (3d Cir. 1972). This case involved an off-duty police officer who pursued and apprehended a driver who allegedly refused to let the officer pass hin. The defendant then beat the driver with a nightstick. The defendant was convicted under $\S 242$ for violating his victim's due process rights. The court stated that although "there was sufficient intent in the instant case, we do not so intinuate that every assault by a police officer . . . ipso facto transfers a state offense to an offense of constitutional dimensions under 18 U.S.C. $\$ 242 . "$ Id. at 161. Nevertheless, the court found enough evidence to support a finding that the defendant had acted under color of law. Id.

133. See 2 Martin A. SChwartZ \& John E. Kirkin, Section 1983 Litigation \& 5.5 , at $254-56$ ( $2 \mathrm{~d}$ ed. 1991).

134. Id. 
broader than, if not at odds with, the definition given in Screws. Moreover, under a broader definition of "under color of law," courts can characterize some traditional crimes as conspiracies to deprive persons of their civil rights. ${ }^{135}$ In other words, by stretching the concept of "under color of law," it is possible to attribute to government defendants the specific intent to deprive persons of their civil rights, thereby transforming a traditional crime into a federal civil rights offense.

Federal courts should cease using section 241 so loosely. ${ }^{136}$ When inquiring into specific intent of a defendant who is charged with violating another individual's constitutional rights, courts should ensure that there was an actual constitutional injury by inquiring into whether the defendant was completely outside the sphere of his legitimate authority when he committed the act that caused the alleged injury. Such a test would weed out convictions of defendants like Robinson and Tarpley who committed ordinary crimes, rather than violations of civil rights. However, the test would itill include within the scope of section 241 situations in which tne defendant's illegitimate conduct was incidental to some legitinate exercise of authority. ${ }^{137}$

Undoubtedly, using section 241 to punisl the excesses of jealous husbands is far removed from the statute's original purpos-

135. For example, in United States v. Fricke, 684 F.2d 1126, 1127-28 (5th Cir. 1982), cert. denied, 460 U.S. 1011 (1983), an off-duty Texas state narcotics agent was involved in an altercation in a dance club. Two police officers arrested the other man involved and drove him to a renote area where the narcotics agent severely beat him. All three officers were charged with a civil rights conspiracy under $\S 241$ and $\S 242$. If private individuals had performed the same actions (kidnapping, assault, and battery), § 241 and § 242 would have been unavailable to federal prosecutors.

136. One commentator has similarly argued that the improper use of $\S 241$ and $\S 242$ has expanded federal power in violation of the principles of federalism. See Malone, supra note 18, at 205.

137. See, e.g., United States v. O'Dell, 462 F.2d 224 (6th Cir. 1972) (depriving arrestees of their right to a fair trial for driving drunk, although initial arrest for drunk driving was legitimate exercise of power). Consider also the Rodney King incident. In that case, Officer Lawrence Powell beat King repeatedly with a nightstick while his superior officer, Sergeant Stacy Koon, stood by and watched. Both officers could be shown to have had the specific intent to violate $\$ 242$ by depriving King of his due process rights to a fair trial by inflicting punishment on him before trial. If the incident had been premeditated, the officers could have been charged with a civil rights conspiracy under $\S$ 241. In the federal civil rights trial of Koon and Powell, the jury found them guilty of violating \& 242. See United States v. Koon, No. CR 92686 JGD, 1993 WL 387860, *1 (C.D. Cal. Aug. 4, 1993); see also Robert Reinhold, Calm Relief Where Rage Once Ruled, N.Y. TIMES, April 18, 1993, at A1, A32. 
es. Indeed, as the variety of cases involving the statute demonstrates, section 241 has blossomed into a sweeping conspiracy statute, despite the Supreme Court's exphcit warning in Anderson $v$. United States ${ }^{138}$ not to transform the statute into a "dragnet" for all conspiracies. ${ }^{139}$

Courts have expanded section 241's scope to reach not only official misconduct traditionally punishable under state law but also private conduct that Congress may not have intended to criminalize, as demonstrated in United States v. Lee. ${ }^{140}$ In Robinson and Tarpley, the courts incorrectly found that the official misconduct fell within the ainbit of certain constitutional guarantees. Likewise, in Lee, the court incorrectly found that a federal statute guaranteeing citizens the right to enjoy housing free from the threat of force prohibited the defendant's conduct. ${ }^{141}$ Having broadly defined the victims' protected interests, the court attributed to the defendant the intent to violate section 241. As discussed below, however, the First Amendment should have shielded the defendant's conduct from prosecution.

\section{Creating a False Conflict Between Section 241 AND THE FIRST AMENDMENT}

In R.A.V. v. City of St. Paul, ${ }^{142}$ the U.S. Supreme Court held that an ordinance proscribing hate speech targeted at minorities violated the First Amendment. In light of this ruling, federal prosecutors are likely to resort to section 241 to target hate crimes with increasing frequency because section 241 does not suffer from the same constitutional infirmities as the ordinance struck down in R.A.V. ${ }^{143}$ Prior to the Court's decision in R.A.V., prosecutors had already used section 241 to pumsh perpetrators of hate crimes, as

138. 417 U.S. 211 (1974).

139. "[C]harges of conspiracy are not to be made out by piling inference upon inference, thus fashioning . . . a dragnet to draw in all substantive crimes." Id. at 224 (quoting Direct Sales Co. v. United States, 319 U.S. 703, 711 (1943)).

As previously noted, $\S 241$ 's scope has also raised concerns about vagueness and federalisin, especially when used to target conduct traditionally within the realm of the states' penal authority. See supra note 22 , notes $44-48$ and accompanying text.

140. 935 F.2d 952 (8th Cir. 1991), opinion and judgment vacated as to Count I, id. at 960, rev'd and remanded, 3 F.3d 1297 (8th Cir. 1993) (en banc) (per curiam).

141. See 42 U.S.C. \& 3631(a) (1988).

142. 112 S. Ct. 2538 (1992).

143. See infra note 152 and accompanying text. 
in United States $v$. Greer, ${ }^{144}$ which involved the vandalism of a synagogue. Section 241 also has been used to punish racially motivated conduct similar to that targeted by the ordinance in R.A.V. ${ }^{145}$

\section{A. Ushering in the First Amendment}

Section 241 seeks to regulate conduct rather than speech; ${ }^{146}$ in other words, section 241 is a content-neutral statute. ${ }^{147}$ Nevertheless, its application may infringe on constitutionally protected speech. Therefore, the intermediate scrutiny test articulated in United States $v$. O'Brien determines its constitutionality under the First Amendment. ${ }^{148}$ At its core, this test balances the state's compelling interest in regulating certain conduct against the First Amendment rights of those whose speech is incidentally infringed by the regulation. If the state can achieve its goal through a narrower regulation, the court will hold that the statute impermissibly interferes with the individual's freedoin of expression. ${ }^{149}$

144. 939 F.2d 1076 (5th Cir.), reh'g granted, 948 F.2d 934 (5th Cir. 1991), reinstated in part on reh'g en banc, 968 F.2d 433 (5th Cir. 1992), cert. denied, 113 S. Ct. 1390 (1993).

145. See, e.g., United States v. Skillman, 922 F.2d 1370 (9th Cir. 1990), cert. dismissed, 112 S. Ct. 353 (1991) (affirming conviction of defendant of violating $\S 241$ and 42 U.S.C. $\S 3631$ (a) by burning a cross on an African-American family's lawn); United States v. Worthy, 915 F.2d 1514, 1514 (11th Cir. 1990) (affirming conviction of defendants of conspiracy to interfere with the rights of an African-American family to "rent, lease, purchase, occupy and hold a dwelling without injury, intimidation or interference because of their race or color" by burning a cross in the family's yard); United States v. Salyer, 893 F.2d 113 (6th Cir. 1989) (affirming conviction of defendant of violating $\S 241$ and 42 U.S.C. \& 3631(a) by burning a cross on an African-American family's lawn). Sometimes, the act of cross burning is accompanied by other acts of violence. See, e.g., United States v. Gresser, 935 F.2d 96, 99 (6th Cir.), cert denied 112 S. Ct. 239 (1991) (cross burning accompanied by dynamite explosion on vacant lot near victims' homes).

146. ABRAMS \& BEALE, supra note 81 , at 589 .

147. A content-neutral statute targets the "noncommunicative impact" of conduct but may be constitutionally impaired if it "unduly constrict[s]" protected speech. LAURENCE H. Tribe, American Constitutional Law § 12-2, at 792 (2d ed. 1988).

148. 391 U.S. 367, 376-77 (1968). See generally TRIBE, supra note 147, § 12-23, at 982 ("Unless the inhibitiou resulting from a content-neutral abridgment is sigmificant, government need show no more than a rational justification for its choice .....").

149. Under O'Brien, a statute that incidentally regulates speech or expressive conduct inust meet four tests. First, the regulation nust be within the government's power. Second, the statute must be content-neutral; in the language of $O^{\prime} B r i e n$, the purpose of the statute must be "unrelated to the suppression of free expression." In addition, the statute nust "further[] an important or substantial governmental interest." Finally, its "incidental restrictiou on alleged First Amendment freedoms [may be] no greater than is essential to the furtherance of that interest." O'Brien, 391 U.S. at 377. 
Because section 241 is content-neutral, it is not unconstitutional under the Supreine Court's ruling in R.A.V. In that case, the Court struck down a St. Paul, Minnesota ordinance that proscribed fighting words expressing hostility to others on the "basis of race, color, creed, religion or gender" and prohibited the display, on both private and public property, of burning crosses or Nazi swastikas. ${ }^{150}$ The inajority found that the ordinance was "facially unconstitutional in that it prohibit[ed] otherwise permitted speech solely on the basis of the subjects the speech addresses." other words, the ordinance was viewpoint specific. Section 241 , by contrast, does not target certain viewpoints but is content-neutral; it regulates "conduct aimed at depriving individuals of their constitutional [or statutory] rights," regardless of the race of the victim or the viewpoint of the actor. ${ }^{152}$

In Lee, the implicated conduct was the defendant's cross burning. Cross burning per se is protected as expressive conduct. ${ }^{153}$ Nevertheless, under the rationale of Brandenburg v. Ohio, ${ }^{154}$ burning a cross on the 'victim's property receives ininimal protection under the First Amendment because it is tantamount to inciting the intended audience to imminent violence or to making the audience fear imminent violence. ${ }^{155}$ When a cross is burned adjacent to, but not on, the victim's property, the First Amendinent

150. R.A.V. v. City of St. Paul, 112 S. Ct. 2538, 2541 (1992).

151. Id. at 2542 .

152. ABRAMS \& BEALE, supra note 81 , at 589.

153. See R.A.V., $112 \mathrm{~S}$. Ct. at 2547 (holding that ordinance targeted at hate speech, such as cross burning, was viewpoint specific and hence unconstitutional); Texas v. Johnson, 491. U.S. 397, 406 (1989) (ruling that flag burning at political demonstration implicated First Amendment protection because of its communicative elements); Brandenburg v. Ohio, 395 U.S. 444, 448-49 (1969) (concluding that criminal syndicalism statute used to prosecute the leader of $\mathrm{Ku}$ Klux Klan rally in which a cross was burned unconstitutionally punished political advocacy). It is not the purpose of this Note to argue either normatively or analytically that cross burning is protected speech under the First Amendment. For the purposes of this Note, it is sufficient to observe that current First Amendinent doctrine deenis cross burning to be a protected activity.

154. In Brandenburg, the Court held that the government could not prosecute a speaker who burned a cross during a rally in which lie called for the return of Jews to Israel and African-Americans to Africa unless the government proved that his speech would incite the crowd to imminent and lawless violence. See Brandenburg, 395 U.S. at $448-49$.

155. The ordinance in R.A.V. proscribing cross burning did not seek to forbid all fighting words or all acts that could incite an audience to violence; rather, the ordinance impermissibly selected those acts that conveyed a message of racial intolerance. R.A.V., 112 S. Ct. at 2547. 
picture is less clear. Such cases fall in a gray zone between what the Brandenburg Court suggested was proscribable activity and what the same Court held was protected activity.

Several recent cases have involved the use of section 241 to prosecute persons who have burned crosses on the front lawns of their intended victims. ${ }^{156}$ For example, in United States $v$. Long, ${ }^{157}$ an African-American family moved into a rural, allwhite area in northwestern Florida and within a few days was greeted with a burning cross on the front lawn. Those responsible for the act were prosecuted under section 241 for conspiracy to interfere with the victims' federal housing rights guaranteed by 42 U.S.C. $\S 3631(\mathrm{a}) .^{158}$ Similarly, United States v. Gresser ${ }^{159}$ involved a cross burning accompanied by an explosion of dynamite on an empty residential lot located adjacent to the homes of two African-American families. The Gresser defendants also were convicted under section 241 for conspiring to violate section 3631(a) ${ }^{160}$ Because the crosses were burned on the lawn, the proximity to the victim made the act tantamount to a threat of violence or an mcitement of the audience to imminent violence. ${ }^{161}$ Thus, the cross burning in these cases was not protected activity.

Moreover, the mens rea requirement of section 241 was clearly satisfied in these cases. The defendants exhibited a clear purpose to use the threat of force to interfere with the exercise of African-

156. The underlying predicate right for such convictions is often supplied by $\S$ 3631(a), which guarantees the right to hive in one's dwelling free from the threat of violence on account of one's race. The statute provides,

Whoever, whether or not acting under color of law, by force or threat of force willfully injuries [sic], imtimidates or interferes with, or attempts to injure, intimidate or interfere with-

(a) any person because of his race, color, religion, sex, handicap . . . familial status ... or national origin and because he is or has been selling, purchasing, renting, financing, occupying ... any dwelling ... .

shall be fined not more than $\$ 1,000$, or imprisoned not more than one year, or both.

42 U.S.C. $\$ 3631$ (a) (1988).

157. 935 F.2d 1207 (11th Cir. 1991).

158. Id. at 1209 .

159. 935 F.2d 96 (6th Cir.), cert. denied, 112 S. Ct. 239 (1991).

160. Id. at $98-99$.

161. Although the intended audience in most cross burning cases reacts with fear, such conduct also can cause the audience to react violently. In Munger v. United States, 827 F. Supp. 100 (N.D.N.Y. 1992), a father attempted to destroy a cross blazing outside his home with an axe before his daughter could see it but was forced to flee into his home after the defendant threatened him. 
Americans' housing rights. The defendants were aware that a burning cross is a symbol of hatred against African-Americans and that by burning a cross on the premises of an African-American family's home, their actions created the specter of imminent violence against African-Americans. To that extent, the defendants' conduct constituted a violation of 42 U.S.C. $\S 3631$ (a). Because both cases involved a conspiracy to deprive the victims of their civil rights as guaranteed by a predicate federal right, section 241 was also properly invoked.

The most remarkable cross burning case involving a section 241 prosecution, however, is United States $v$. Lee. Unlike the aforementioned cases, Lee involved no accoinpanying acts of violence. Moreover, the cross burning did not occur on the property of the intended audience, but more than 100 yards away froin their residence. ${ }^{162}$ Although such conduct in some circumstances could create the specter of imminent violence, there was no such showing in $L e e .^{163}$ In short, the cross burning in Lee was protected activity under the Brandenburg standard. Accordingly, the Lee case demonstrates a potential conflict between section 241 and the First Amendment.

\section{B. United States v. Lee: Making a Sham of Mens Rea}

This Section explores the analysis in both the Eighth Circuit's panel $^{164}$ and en banc ${ }^{165}$ decisions in United States v. Lee. The focus of this Section is on the fundainental error that the panel decision made: instead of defining the predicate right and engaging in proper mens rea analysis to determine whether the defendant's conviction was sustainable, the court rushed into a First Amendment issue it should not have reached, namely, whether section 241 was unconstitutional as applied. The en banc plurality opinion correctly defined the predicate right involved, but it too raced

162. The defendant burned the cross in an "open field behind the complex ... on a small hill some 386 feet away from the apartment buildings." Brief for Appellant at 4, United States v. Lee, 935 F.2d 952 (8th Cir. 1991) (No. 90-5264).

163. The cross burned only briefly. Lee, 935 F.2d at 954. Moreover, there was no rally of any kind, no epithets were shouted, and no shots were fired. The fact that the intended victims were targeted in their hoines is insufficient by itself to meet the Brandenburg standard. See infra notes 175, 194 and accompanying text.

164. 935 F.2d 952 (8th Cir. 1991), opinion and judgment vacated as to Count $I$, id. at 960, rev'd and remanded, 6 F.3d 1297 (8th Cir. 1993) (en banc) (per curiam).

165. 6 F.3d 1297 (8th Cir. 1993) (en banc) (per curiam). 
ahead of itself to reach the issue of section 241's unconstitutionality. Regrettably, it incorrectly found that section 241 failed the $O$ 'Brien test as apphed to the defendant. Although the en banc court reversed and remanded Lee's section 241 conviction, a thorough discussion of the panel court's decision to affirm his conviction is appropriate because the reasoming serves as a paradigm model of the failure of some courts to properly define the protected interest and apply the mens rea requirement.

1. The panel decision in United States v. Lee. The defendant in United States v. Lee was convicted for his participation in an incident occurring during a visit to his girlfriend's apartment in Coon Rapids, Minnesota. Lee, his girlfriend, and some Caucasian tenants discussed recurring probleins with some of the children in Lee's girlfriend's apartment complex, including the recent assault of a Caucasian child by an African-American child. One of the residents suggested to Lee that they burn a cross, and Lee agreed. Around ten o'clock that evening, he changed into dark clothes, donned a white inask, and burned a cross on a hill 386 feet away from the apartment coinplex. An elderly woman in the complex testified to seeing the burning cross and being afraid of the $\mathrm{Ku}$ Klux Klan. ${ }^{166}$

Lee was charged with conspiring to interfere with the housing rights of citizens because of their race by means of force or threat of force in violation of 18 U.S.C. $\S 241$. The predicate right was provided by 42 U.S.C. $\S 3631(a),{ }^{167}$ Lee also was charged with violatimg section 3631(a) itself. The jury convicted him on the conspiracy count under section 241 but acquitted hin on the charge of violating 42 U.S.C. $\S 3631(\mathrm{a}){ }^{168}$

Lee appealed, alleging that cross burning is expressive conduct protected by the First Amendment and that section 241, as applied to him, violated his free speech rights. ${ }^{169}$ A panel of the U.S. Court of Appeals for the Eighth Circuit rejected his arguments, holding that section 241 is constitutional under the O'Brien analy-

166. Lee, 935 F.2d at 954 .

167. Id. at 953.

168. Id.

169. Lee also contended that $\S 241$ was overbroad. Id. at 954. The Court disagreed, holding that $\S 241$ "does not reach a substantial amount of constitutionally protected conduct." Id. at 955. 
sis. ${ }^{170}$ Applying the $O^{\prime} B r i e n$ test, the court first determined that the statute was content-neutral: "Section 241 does not prohibit conspiracies to communicate offensive or racist messages; it does not prohibit conspiracies to simply burn a cross. Section 241 is a content neutral statute which prohibits conspiracies to threaten or intimidate others im the exercise or enjoyment of their federally guaranteed rights." 171 The court then determined that section 241 served a substantial government interest and was narrowly tailored to meet the underlying government interest: . $^{172}$ "Section 241 is a narrowly tailored law which targets and eliminates the exact source of 'evil' it seeks to remedy by requiring a strict scienter requirement .... If the specific intent is absent, the statute does not restrict first amendment freedom." 173 The court concluded that the statute did not criminalize conduct unless the defendant demonstrated a deliberate purpose to interfere with an individual's enjoyment of his rights.

Contrary to the court's conclusions, its application of section 241 impermissibly infringed on Lee's protected First Anıendment rights. Lee's cross burning was expressive conduct protected by the First Amendnient. The imcident occurred almost 400 feet away from its intended audience; one cannot draw an analogy between this conduct and burning a cross on the victim's front lawn. Moreover, Lee and his co-conspirators did not commit other acts of violence or accompany their act with verbal threats targeted at African-Americans. Under the Brandenburg standard, the government cannot proscribe fighting words, such as racial epithets, unless they would provoke imminent and lawless violence. ${ }^{174}$ The fact that

170. Id. at 955 .

171. Id. at $954-55$.

172. Id. at 955; see supra note 149.

173. Lee, 935 F.2d at 955.

174. This proposition may be of dubious worth in light of the dictum in Justice Scalia's opinion in R.A.V. v. City of St. Paul, 112 S. Ct. 2538 (1992). Justice Scalia suggested that if the city had used "[a]n ordinance not limited to the favored topics," but one that proscribed all fighting words, the ordinance "would have precisely the same beneficial effect" and would presumably be constitutional. Id. at 2550; see id. at 2553 (White, J., concurring) ("Should the government want to criminalize certain fighting words, the Court now requires it to criminalize all fighting words."); id. at 2562 (Stevens, J., concurring) ("[W]ithin a particular 'proscribable' category of expression, the Court holds, a government must either proscribe all speech or no speech at all.").

Justice Scalia also opined that although fighting words convey ideas that are protected under the First Amendinent, "the reason why fighting words are categorically excluded froin the protection of the First Amendinent is not that their content communi- 
expressive conduct may be intimidating is not enough to meet the Brandenburg standard. ${ }^{175}$ Lee's conduct was intimidating but not imminently and actually harmful. ${ }^{176}$

Ironically, the majority was correct in its conclusion that section 241 satisfies the O'Brien test. The majority reasoned that the specific intent element of the statute ensured that speech alone would not be criminalized. If Lee had the "specific intent to threaten or intimidate another person in the exercise or enjoyment of a federally guaranteed right," 177 it was not necessary to show that violence was likely to occur from his expressive conduct. The statute punishes the intent to conspire, not the conduct attendant to the conspiracy, and the act of cross burning can serve as evidence of intent. The First Amendment, nuoreover, does not prevent the prosecutor from using protected expression to prove a conspiracy. ${ }^{178}$

Nonetheless, the court's application of section 241 violated Lee's First Amendment rights not because section 241 incidentally infringed on Lee's speech but because the majority erred in its relaxed construction of section 241's specific intent requirenient.

cates any particular idea, but that their content embodies a particularly intolerable (and socially unnecessary) mode of expressing whatever idea the speaker wishes to convey." Id. at 2548-49. Thus, if the city ordinance had proscribed all fighting words that fell into this category, rather than just racial epithets, it might have been constitutional.

By the same token, if the city had promulgated an ordinance that proscribed all expressive conduct that was "socially unnecessary" to convey an idea, rather than just certaim forms of conduct (e.g., wearing swastikas or burning crosses), the statute might have been constitutional. Under such a statute, cross burning could be proscribed regardless of whether the particular act was likely to incite someone to imminent and actual violence.

175. The dissent cited three famous cases in First Amendment jurisprudence involving forceful speech held to be protected by the First Amendment: NAACP v. Claiborne Hardware Co., 458 U.S. 886 (1982) (finding that the First Amendment protected the boycott of merchants accompanied by threatening statements specifically advocating reprisals against those who did not comply with the boycott); Brandenburg v. Ohio, 395 U.S. 444 (1969) (finding that the First Amendment protected a Ku Klux Klan rally in which the speaker advocated the return of Jews to Israel and African-Americans to Africa); and Collin v. Smith, 578 F.2d 1197 (7th Cir.) (finding that the First Amendment protected a Nazi Party march through a predominantly Jewish neighborhood in Skokie, Illinois), cert. denied, 439 U.S. 916 (1978). Lee, 935 F.2d at 959 (Arnold, J., dissenting).

176. The Frisby doctrine, which holds that speech can be regulated where an unwilling captive audience is involved, Frisby v. Schultz, 487 U.S. 474, 484-85 (1988), is also inapplicable because the cross was alnost 400 feet away from the apartment complex. Lee, 935 F.2d at 960 (Arnold, J., dissenting).

177. Lee, 935 F.2d at 955 .

178. See Wisconsin v. Mitchell, 113 S. Ct. 2194, 2201 (1993). 
Neither the court nor the government demonstrated that the defendant had the requisite state of mind to violate section 241 . In failing to do so, the Lee court cominitted the same error as the Ehrlichman court-specifically, reducing the mens rea the statute requires.

The court's discussion of Lee's specific intent to conspire to interfere with fair housing rights is problematic. The court structured its analysis as if it were affirming Lee's conviction for violating 42 U.S.C. $\S 3631$ (a), rather than his conviction for conspiring to violate it. The court stated that

[t]he jury, of course, was aware of the circumstances of Lee's conduct. The jury could readily have found that Lee's conduct was tantamount to intimidation by threat of physical violence. It was not mere advocacy, but rather an overt act of intimidation which, because of its historical context, is often considered a precursor to or a promise of violence against black people. Upon the record evidence, the jury could have found that the crossburning was an especially intrusive act which mvaded the substantial privacy interests of its victins in an essentially intolerable mauner. ${ }^{179}$

Rather than engage in a conspiracy analysis, which would have focused on whether there was enough evidence to conclude that Lee intended to violate section 3631(a), the court unwittingly sought to prove that there was enough evidence to find that Lee committed the actus reus prohibited by section 3631(a). ${ }^{180}$

The majority's focus on Lee's conduct is indicative of its failure to inquire properly into Lee's mens rea: instead of requiring

179. Lee, 935 F.2d at 956. The court referred to the "privacy interests" of the victims of Lee's conduct, although $\S 3631$ (a) contains no mention whatsoever of "privacy interests." The purpose of the statute is to protect the basic civil right of owning or occupying a home.

180. Moreover, the court's conclusion that Lee's conduct could have violated $\S 3631$ (a) is also suspect. First, as Judge Arnold notes in his dissent, the jury acquitted Lee on this charge. Second, it is doubtful that burning a cross 386 feet away from the apartment is sufficient to result in a violation of $\S 3631(\mathrm{a})$. The statute is not violated without the use of force or threat of force. See United States v. Redwine, 715 F.2d 315, 317-18 (7th Cir. 1983) (defendants convicted under $\$ 3631(\mathrm{a})$ for firebombing home of an African-American family), cert. denied, 467 U.S. 1216 (1984); United States v. Johns, 615 F.2d 672, 674-75 (5th Cir.) (defendants convicted under $\$ 3631$ (a) for firing shots into the homes of local NAACP leaders), cert. denied, 449 U.S. 829 (1980). If burning a cross 386 feet away from the complex was sufficient to violate $\$ 3631(\mathrm{a})$, the statute could be struck down on First Amendinent grounds. See supra note 175 and accoinpanying text. But see supra note 174. 
that Lee have the specific intent to cause a civil rights deprivation, it required only that he have the specific intent to commit an act of intimidation that supposedly caused a deprivation. ${ }^{181}$ In other words, instead of requiring a specific intent to interfere with the housing rights of citizens by threat of force, the majority upheld Lee's conviction on evidence proving only that he conspired to commit the act of cross burning. ${ }^{182}$

The court's mens rea analysis was imbued with error in part because it failed to properly define the predicate right. Although section 241 speaks of conspiracies to "imjure, oppress, threaten or intimidate" someone in the enjoyment of his rights, this language turns on the predicate right, which, together with section 241, defines the precise substance of the offense. In this case, the protected interest was the enjoyment of housing rights secured by 42 U.S.C. \& 3631(a). That statute granted the African-Americans in the coinplex the right to enjoy their homes without interference by force or the threat of force on account of their race. ${ }^{183}$ Thus, although section 241 employs the language "intimidate," section 3631 (a) requires force or the threat of force, thereby requiring the prosecution to show more than mere intimidation. The court's analysis, however, obliterates this distinction.

To support its faulty conclusion, the court seized on Lee's admission that lie intended to frigliten the African-American residents of the complex to mipute to lim the intent to violate section $241{ }^{184}$ Obviously, the defendant's mean-spirited act was intended to scare African-American residents, but a section 3631(a) violation requires at least a threat of force. If the inajority had actually demanded that the prosecutor slow evidence of specific intent to

181. Cf. United States v. Fricke, 684 F.2d 1126, 1128 (5th Cir. 1982), cert. denied, 460 U.S. 1011 (1983) (approving same jury instructions for $\S 241$ and $\S 242$, which defined the requisite specific intent as purpose to commit the act that causes the deprivation).

182. As the dissent notes, not every act of intimidation is also a threat to use force. See Lee, 935 F.2d at 959 (Arnold, J., dissenting); supra note 175.

183. See supra note 156.

184. The court was forced to enphasize the historical context of cross burning to justify its conclusion that Lee's conduct sufficed to show a conspiracy to interfere with the housing rights of African-Americans. The premise of the court's analysis is that cross burning can be objectively understood as a threat against African-Aunericans. In this regard, the majority noted the testimony of a seventy-one-year-old African-American woinan who testified that cross burning is a "form of intimidation .... [A] lot of the cross burnings in the south during the civil rights movement preceded hangings and that sort of thing. Of course, being a black, that is what it calls to mind." Lee, 935 F.2d at 956 n.5. 
use force to interfere with the housing rights of African-American families, it would have been forced to confront the paucity of the evidence. The facts as alleged by the government fail to show that Lee conspired to use force or threats of force against AfricanAmericans living in the complex. ${ }^{185}$ In effect, the court cliaracterized the cross burning as a threat of force, although the Brandenburg standard precludes sucl a conclusion by requiring a showing of imminent or actual harm before symbolic speech is demied First Amendment protection.

Presumably inotivated in part to see the defendant punished for his deed, the Lee court committed the same errors other courts eager to affirm section 241 convictions liave inade. The Lee court quickly found that the defendant's conduct fell within the ambit of section 3631(a). As in Robinson and Tarpley, the court coinpletely overlooked the important step of defining the federal right that the defendant supposedly conspired to violate, rendering the mens rea analysis meaningless. Brushing aside a careful reading of the statute, all three courts superficially concluded that the defendant's conduct dernonstrated an intent to violate section 241 .

The dissent in Lee disputed the majority's assertions that the defendant's speecli rights were not violated. Judge Arnold, although agreeing with the majority that the statute was facially content-neutral, found that the trial court's constrnction of section 241 was not narrowly tailored to ineet the government's interest. ${ }^{186} \mathrm{He}$ attempted to define that interest involved consistently witl the First Amendment: "I would define the interest as follows: the right to be free of physical force, or threats of physical force. Section 241, of course, says nothing about force." 187 According to

185. See id. at 957. Other than the act of cross burning, the only evidence of specific intent the majority could point to was Lee's statement that he hoped that by burning a cross, "[m]aybe that would get rid of some of the bad blacks that were [living in the complex], they would take the message seriously and leave." Id. at 954. Clearly, Lee intended to intimidate African-Americans living in the coinplex, but intimidation is not enough to violate 42 U.S.C. $\$ 3631$ (a). See, e.g., United States v. Redwine, 715 F.2d 315, 317-18 (7th Cir. 1983), cert. denied, 467 U.S. 1216 (1984). The proper inquiry asks whether a defendant intends to use any force or threat of force to interfere with his victim's ability to rent and occupy their apartments. The majority sidestepped this question in its opinion, but it is crucial in determining whether Lee lad the necessary specific intent under $\$ 241$.

186. Id. at 958-59 (Arnold, J., dissenting).

187. Id. at 959 . The relevant language of $\S 241$ bars a "conspir[acy] to injure, oppress, threaten, or intimidate any inlabitant ... in the free exercise or enjoyinent of any right 
Judge Arnold, the district court exacerbated the First Amendment problem by instructing the jury that section 241 criminalizes conduct not involving the use of force or threat of force. In defining what the statute meant by "intimidating" anyone in the "enjoyinent" of his federal rights, the trial judge told the jury that section 241 "covers 'a variety of conduct intended to harm, frighten, punish, or inhibit the free action of other persons." "188 Judge Arnold noted that the trial court's defimition of "intimidation" would criminalize pure speech. ${ }^{189} \mathrm{He}$ suggested that when the defendant's conduct involved speech activity, the jury should be required to find that the defendant's "threats and intimidation involved an imminent use of force, or at least caused [his intended victims] to fear that force was imminent." ${ }^{190}$ Under the majority's interpretation of section 241, the defendant could be found to have intimidated the residents of the apartments if he had distributed leaflets "stating that the Ku Klux Klan was in the neighborhood, disliked black people, and wanted them to move out."191

Not coincidentally, the dissent's analysis is equally impaired by its failure to examine the underlying statute to determine the protected interests of Lee's victims, thereby overlooking the fact that section 3631(a) precludes a conviction without, at a minimum, evidence that the defendant threatened to use force. Instead, the dissent's analysis was based on the false premise that section 241 was properly apphed. Thus, the dissent rushed to the erroneous conclusion that section 241 needed to be narrowly tailored by requiring that the threat of force be shown in cases involving expressive conduct.

Although the dissent is mistaken im its conclusion that section 241 should be narrowly tailored to avoid infringing on protected conduct, it correctly notes that the majority's loose construction of section 241 potentially implicates free speech. To demonstrate the consequences of the majority's analysis, consider the events giving rise to Collin v. Smith. ${ }^{192}$ In that case, the National Socialist Party of America sought injunctive relief from the enforcement of three ordinances designed to prevent them from marching in Nazi

\footnotetext{
or privilege." 18 U.S.C. $\S 241$ (1988). For the full text of the statute, see supra note 1. 188. Lee, 935 F.2d at 959 (quoting the district court's jury instructions).

189. Id.

190. Id. at 960 .

191. Id.

192. 578 F.2d. 1197 (7th Cir.), cert. denied, 439 U.S. 916 (1978).
} 
uniforms through the town of Skokie, Illinois, which was heavily populated by Holocaust survivors. ${ }^{193}$ Under the Lee majority's rationale, the Nazi Party marchers in Collin possibly could have been convicted under section $241 .{ }^{194}$ Because the Lee majority required only that the jury find that the defendant had the purpose to commit acts of intimidation, the-Nazi party marchers could be said to have conspired to interfere with the rights of Jewish citizens to own and occupy dwellings free from intimidation on account of their religion and ethnicity.

2. The en banc decision in United States $\mathrm{v}$. Lee. Recognizing the First Amendment implications of the panel's holding in Lee, the Eighth Circuit, in a per curiam, en banc decision, reversed the defendant's section 241 conviction and renanded for a retrial. ${ }^{195}$ On remand, the district court was directed to instruct the jury that they must "find[] that. Lee's actions were done with the intent to advocate the use of force or violence and were likely to produce such action." 196

Nevertheless, the Eighth Circuit's analysis remains fundamentally flawed because it prematurely focused on section 241's constitutionality under the O'Brien test. The court's confusion is evident in its treatment of the First Amendment issues involved. Whetler the cross burning can be used consistently with Brandenburg as proof of force or the threat of force is a distinct question from whether section 241 is content-neutral or content-based. The en banc opinion conflates these two questions, thus arriving at the erroneous conclusion that the government's interest in section 241, as applied, is related to suppressing the defendant's speech.

193. Id. at 1199.

194. Despite the proximity of the planned march to the homes of Holocaust survivors, the court held that three ordinances the town enacted to prohibit the type of expressive conduct the Nazis planned were unconstitutional. Id. at 1207. Although two of these ordinances were content-based (i.e., directed against conduct advocating hatred or violence against persons on account of race, ethnicity, or religion), see id. at 1199, and hence almost automatically unconstitutional, see R.A.V. v. City of St. Paul, 112 S. Ct. 2538, 2547 (1992), it has been understood that the marches in Skokie were protected First Amendment activity. See, e.g., Caroll v. President of Princess Anne, 393 U.S. 175, 181 (1968) (finding that an ex parte injunction against planned rally of militant white supremacists outside county courthouse violated First Amendment rights of participants).

195. United States v. Lee, 6 F.3d 1297, 1297 (8th Cir. 1993) (en banc) (per curiam).

196. Id. at 1304 (Gibson, J., concurring). 
Using a demanding $O^{\prime}$ Brien standard, the plurality opinion found that section 241, as applied to Lee, failed the O'Brien test because they could not conclude that "under the circuinstances before [them], the governmental interest [was] unrelated to the suppression of free expression."197 This statement is remarkable, given that section 241 is a content-neutral law that regulates conduct, not speech activity. Under section 241 , a proper conviction rests on whether the defendant conspired to interfere with the rights of others, not on the content of his speech. Thus, the appro-priate analysis should follow the four-part O'Brien test. Under that test, it is clear that section 241 is constitutional. As the dissenting opinion noted, "[Section] 241 prohibits conspiracies to interfere with federally protected rights. Congress has the power under the Fourteenth Amendment and under the Cominerce Clause to prohibit interference with the constitutional and legal rights of others."198 Moreover, the Supreme Courrt in O'Brien did not apply strict scrutiny to a congressional statute proscribing the burning of draft cards; otherwise, it surely would have found that the congressional law proscribing the destruction of draft cards, as apphied to O'Brien, was unconstitutional. ${ }^{199}$ The plurahty opinion likened this case more to Cohen $v$. California, ${ }^{200}$ in which the court held unconstitutional a statute proscribing breach of the peace when used against a defendant who displayed the words "Fuck the Draft" on his jacket. ${ }^{201}$ In that case, however, the Court found that " $[t]$ he conviction quite clearly rests upon the asserted offensiveness of the words Cohen used to convey his message to the pubhic."202 In Lee, the government's interest in conviction lies in the protection of the civil rights of AfricanAmericans.

Having apphed a higher standard of scrutiny than O'Brien required, the plurality proceeded to confuse the other First Amendment issue, namely, that surrounding the defendant's cross burning. The fundamental question in the case was whether, under

197. Id. at 1301 (Gibson, J., concurring).

198. Id. at 1308 (McMillian, J., dissenting).

199. See United States v. O'Brien, 391 U.S. 367, 381-82 (1968) (holding that government interest behind congressional statute proscribing destruction of draft cards was unrelated to suppression of speech).

200. 403 U.S. 15 (1971).

201. Id. at 16,26 .

202. Id. at 18 . 
the particular circumstances, the cross burning constituted evidence of force, or the intended use of force, sufficient to show that the defendant conspired to violate section 3631(a). Although the plurality correctly noted that the cross burning must be analyzed under Brandenburg, it remanded the case to the jury for consideration on this count. As Judge Lay noted in dissent, the record of the case was imsufficient to support the conclusion that Lee's cross burning constituted anything more than an act of intimidation. The en banc plurality opinion presented more testimony than the panel decision as to whether Lee's conduct created the fear of imminent violence, but its reasoning remains unconvincing. The plurahty noted that Pearl Jones, an elderly African-American resident, testified to fearing that the building would be burned down at night. ${ }^{203}$ It sidestepped further testimony, however, that Pearl Jones jomed the defendant and his party for beer and pizza after the cross burning and discussed racial problems. ${ }^{204}$ The evidence, moreover, as Judge Lay noted, "show[ed] that Lee's conduct in burning the cross was not directed to inciting imminent lawless action. Lee placed the cross not in front of a particular family's apartment window, but in a field soine 386 feet from the apartment buildings, more than the length of a football field."205 Judge Lay thus concluded "that there existed insufficient evidence to sustain a retrial on the conspiracy count."206

Judge Lay's most important observation, however, was that the extent of the "conspiracy" in this case was the burning of a cross to advocate that "bad blacks should leave" the apartments. ${ }^{207} \mathrm{He}$ further stated that "[i]t is difficult for me to coinprehend why, when the object of the conspiracy-symbolic speech-is not unlawful, the conspiracy (planning of the symbolic speech) may nevertheless be prosecuted."208 The observation that Lee intended no further conduct than the burning of a cross provides an important caveat to this discussion. The application of Brandenburg to preclude the evidentiary use of expressive conduct is appropriate only when both of the following circumstances exist:

203. United States v. Lee, 6 F.3d 1297, 1304 (8th Cir. 1993) (en banc) (per curiam).

204. Id. at 1304 .

205. Id. at 1306 (Lay, J., concurring in part and dissenting in part).

206. Id. at 1304 .

207. Id. at 1307.

208. Id. (citing Texas v. Johnson, 491 U.S. 397 (1989); Boos v. Barry, 485 U.S. 312 (1988)). 
(1) the expressive conduct is the only act that the defendant intended-there is no further proof of other planned acts; ${ }^{209}$ and (2) the expressive conduct is unaccompanied by any other acts of violence or verbal threats. ${ }^{210}$ Should neither of these conditions be present, Brandenburg is inapplicable, as discussed in the next Section.

\section{Implications of Umited States v. Lee for the Use of Section 241}

The plurality's en banc decision in Lee, holding section 241 unconstitutional as applied to the defendant, rests in part on its failure to keep distinct the elements of a section 241 offense. The court forgot that one cannot conspire to violate section 241; one must conspire to violate another protected right. In other words, section 241 only proscribes conduct that interferes with a protected zone of private activity implied from other federal rights. This analysis suggests that an as-applied First Amendment challenge to section 241 should only succeed if the scope of protection secured by the predicate right unconstitutionally implicates protected speech activity.

Consider, for mstance, a variation of Judge Arnold's lypothetical in his dissent in the panel opinion involving the distribution of $\mathrm{Ku} \mathrm{K}$ lux Klan leaflets. Assume that Congress passed a housing rights statute that only proscribed the intimidation of individuals enjoying their housing rights on account of their race, rather than requiring force or the threat of force. Conceivably, people passing out leaflets outside a multi-racial apartment complex stating that the $\mathrm{Ku}$ Klux Klan would be holding a rally advocating the separation of the races would have evidenced the necessary purpose to violate the hypothetical housing statute. If two or more people conspired to violate such a statute, they also would have violated

209. As discussed infra, the Lee case is troubling because it implies that even in cases in which the prosecution has evidence of other planned acts, if the evidence is provided by otherwise protected conduct, such as cross burning, such evidence is to be scrutinized under Brandenburg. This implication, however, is incorrect. Inasınuch as the expressive conduct is evidence of a larger conspiracy, it can be used to prove the defendant's specific intent to conspire consistent with the First Amendment. See infra notes 215-218 and accompanying text.

210. If there were other acts, they could have separately provided the evidence of specific intent. See infra notes 223-25 and accompanying text. Alternatively, threatening acts and speech may change the circunstances enough to remove the cross burning from Brandenburg's protection. 
section 241. However, the hypothetical statute itself would probably fail to withstand First Amendment scrutiny. If the underlying statute unconstitutionally implicated protected conduct, prosecutors could not use it to charge imdividuals with conspiring to violate section 241 in a similar factual context. ${ }^{211}$

To avoid implicating free speecl, however, section 241 need only be properly applied; it need not be narrowly tailored in cases involving protected conduct. Unfortunately, sliould otlier courts be persuaded by the en banc plurality's opimon that section 241 , as applied to Lee, failed the $O^{\prime} B$ rien test, judicial tailoring of section 241 could unnecessarily impede prosecution of true conspiracies to interfere with civil rights. In such cases, the prosecution would lave to overcome the burden of showing that the act of crossburning ineets the heightened requirements tliat Judge Arnold proposed, nainely, that in cases involving speecli activity, section 241 should be read as if it required the defendant to conspire to "use physical force, or threat of physical force" to interfere with another's civil riglits. ${ }^{212}$

To illustrate this point, assume that an individual conspires to use force or the threat of force to interfere with someone else's lousing riglits on account of the victim's race. As part of the conspiracy, the defendant and his co-conspirators plan acts of intimidation, such as spray painting the doors of people's apartments with racial slogans or firing shots at the windows of non-Caucasian residents. Neither of these actions is protected by the First Amendinent, the first because it is tantamount to a threat of force, and the second because it actually constitutes force. ${ }^{213}$ Additionally, the conspirators intend to begin their terrorization by burning a cross (not on the victim's property) or by waving Confederate

211. If the underlying statute proscribed all intimidating conduct (i.e., regardless of whether it was racially motivated) that interfered with housing rights but did not require that the defendant used force or the threat of force in his intimidation, it could be constitutional under the standard set forth in R.A.V.'s dictum. See R.A.V. v. City of St. Paul, $112 \mathrm{~S}$. Ct. 2538, 2550 (1992). If one assumes, arguendo, that $\S 3631$ (a) did not require force or the threat of force but proscribed any intimidation against any individual, and that the dictum in $R . A . V$. is the governing standard, then the Lee court's judgment that $\S$ 241, as applied, did not violate Lee's First Amendment rights would have been correct, even if its analysis was not.

212. United States v. Lee, 935 F.2d 952, 959 (8th Cir. 1991) (Arnold, J., dissenting), opinion and judgment vacated as to Count $I$, id. at 960, rev'd and remanded, 6 F.3d 1297 (8th Cir. 1993) (en banc) (per curiam).

213. See supra notes $155-61$ and accompanying text. 
flags. Assume that the conspirators parade in front of their victims' homes with a Confederate flag but never execute the other planned acts. Technically, under such a scenario, the prosecution should be able to demonstrate to the jury the existence of a conspiracy to interfere with housing rights, even if the expressive conduct provides the only evidence of an overt agreement or of the defendants', specific intent to conspire. ${ }^{214}$

Indeed, even when otherwise protected conduct provides the overt act, it can be used as evidence of a defendant's intent to violate section 241 . The U.S. Supreme Court recently ruled that "[t]he First Amendment ... does not prohibit the evidentiary use of speech to establish the elenients of a crime or to prove motive or intent." 215 Furthermore, as one commentator noted, "Traditional conspiracy law raises no bar to instances of protected speech being considered overt acts in pursuance of a conspiracy or being used to show intent."216 The goal of conspiracy law is to penalize an agreement to violate laws, ${ }^{217}$ not the speech used to form the conspiracy. ${ }^{218}$

Nevertheless, an appellate court sensitive to the First Amendment would be hesitant to affirm a conspiracy conviction under section 241 when protected conduct provided the only overt proof of the conspiracy. After the en banc plurality's startling opinion in Lee, defendants in section 241 hate crime cases involving acts of expressive conduct will probably assert the First Amendment as a defense. Some courts may then accept Judge Arnold's view and require a showing of threatening conduct toward the intended victnns. This requirement, however, could unnecessarily hinder prosecutions of true civil rights conspiracies. There is no reason why individuals who truly conspire to deprive others of their civil rights should escape punishment because the only evidence of their conspiracy constitutes otherwise protected conduct. ${ }^{219}$

214. See Wisconsin v. Mitchell, 113 S. Ct. 2194, 2201 (1993).

215. Id.

216. Kent Greenawalt, Speech and Crime, 1980 AM. B. Found. REs. J. 645, 777.

217. LAFAVE \& SCOTT, supra note 51, § 6.4(a).

218. An exception to this statement is provided by conspiracy laws outlawing political association or speech activities, such as criminal syndicalism statutes. See Note, Conspiracy and the First Amendment, 79 YALE L.J. 872, 894 (1970) (arguing that courts should "bar the use of constitutionally protected public expression as evidence" to prove a conspiracy).

219. Another hypothetical further illustrates this point. Assume law enforcement officials learn from an informant that a group of individuals plans to attack interracial 
Not surprisingly, a recent case, United States v. McDermott, ${ }^{220}$ deinonstrates that the panel opinion in Lee may already have burdened section 241 with unnecessary First Amendnent analysis. In McDermott, the court denied the defendants' motions to dismiss the section 241 charges against thenl. ${ }^{221}$ The defendants were charged with conspiring to prevent African-Americans froin using Comisky Park in Dubuque, Iowa. ${ }^{222}$ The defendants allegedly yelled racial slurs and threats, brandished weapons at African-Americans to nitimidate then from using the park, and burned a cross in the park. ${ }^{223}$ The underlying right for the section 241 conspiracy charge was provided by 42 U.S.C. $\$ 2000 \mathrm{a}$ (a), which guarantees individuals the right to enjoy public accommodations without discrimination on the basis of race. ${ }^{224}$

On the alleged facts, there was clearly enough evidence, even without the act of cross burning, to allow the government to go forward with its prosecution of the defendants under section 241. The defendants threatened African-Americans in the park with weapons and shouted slurs and threats at them. These facts showed that the defendants had the purpose to conspire to prevent African-Americans from using Comisky Park.

The court, however, allowed itself to be sidetracked by the defendants' arguments that the act of cross burning was a protected exercise of free speech. If the act of cross burning had been an isolated event, unaccompanied by the brandishing of weapons and the yelling of threats at African-Americans in the park, the defendants' conduct would have been closer to that in Brandenburg v. Ohio. ${ }^{225}$ As other threats of violence occurred ni

couples using a public park; assume further that the police are alerted to this plan and arrest a group of men parading around in white robes in the park and carrying banners with swastikas on them. If there is a connection between the conspiracy to attack interracial couples and the men arrested in the park, would prosecutors be able use the speech activity of the men in the park to demonstrate the overt act and specific intent needed to prove a conspiracy? Under traditional conspiracy law, there should be no bar to this use of such evidence. See supra notes $215-18$ and accompanying text. If, lowever, the rationale in Judge Amold's dissent is persuasive to a reviewing court, the defendants may go free simply because there was no showing of imminent or actual force.

220. 822 F. Supp. 582 (N.D. Iowa 1993).

221. Id. at 583. The defendants also were charged with violating 18 U.S.C. § 245 (b)(2)(B) (1988), which prohibits the use of force or threat of force to interfere with a person's right to enjoy public accommodations on account of his race. Id. at 584 .

222. McDermott, 822 F. Supp. at 583.

223. Id.

224. 42 U.S.C. $\$ 2000 \mathrm{a}(\mathrm{a})(1988)$.

225. 395 U.S. 444 (1969) (holding that cross burning in a park at a political rally is 
the same context, however, the court should have treated the cross burning as another overt act demonstrating a conspiracy to deprive African-Americans of the use of the park. This scenario differs markedly from the situation in Lee, in which the only act the defendant committed, or for that matter planned to commit, was the burning of a cross as a scare tactic.

Nevertheless, the McDermott court launched into a lengthy discussion of the First Amendment issues, citing the "important" panel opimion in Lee. ${ }^{226}$ The court discussed content-based scrutiny, ${ }^{227}$ content-neutral (O'Brien) scrutiny, ${ }^{228}$ public forum scrutiny, ${ }^{229}$ and overbreadth analysis. ${ }^{230}$ After an impressive display of First Amendment knowledge, the court concluded that under either content-based or content-neutral analysis, the cross burning constituted a "threat of racial violence" and was therefore not protected speech. ${ }^{231}$

The court's First Amendment analysis is unnecessary. ${ }^{232}$ As noted, the defendants' alleged conduct provided evidence of their

protected speech). The McDermott court, however, suggested that such a case could differ from Texas v. Johnson, 491 U.S. 397 (1989), which held that flag burning was protected speech, and noted that the cross burning "was not performed at an overtly political demonstration." McDermott, 822 F. Supp. at 588 n.6. Whether a cross burning occurs at a pohitical demonstration, however, does not deprive it of its speech value. See R.A.V. v. City of St. Paul, 112 S. Ct. 2538 (1992) (finding that cross burning on private lawn involves commumicative elements).

226. McDermott, 822 F. Supp. at 586.

227. Id. at 590-92 (concluding that even under strict scrutiny, $\S 241$, as applied in the instant case, survived challenge).

228. Id. at 592-94 (concluding that $\$ 241$ met the O'Brien criteria).

229. Id. at 594-95 (concluding that public forum analysis overlapped with $O^{\prime} B$ rien analysis and that $\$ 241$ survived public forum analysis).

230. Id. at 595-96 (concluding that $\S 241$ was not overbroad or impermissibly vague).

231. Id. at 593 .

232. After extensive discussion of content-based and content-neutral analysis, the court simply concluded that because it was disposing of the defendant's motion to dismiss, it "need not resolve whether the effects on protected speech are incidental," id., or whether $\S 241$ should be analyzed as a content-based statute, see $i d$. at 590 . Under either analysis, the court suggested, the alleged cross burning in the instant case was not protectcd speech but constituted unprotected threats against African-Americans. Id. at 591, 593. Besides representing a questionable expenditure of judicial resources, the court's analysis is not helpful at all because the court failed to give any specific facts of the alleged cross burnimg. The court merely stated that the indictment charged the defendants with participating in a cross burning in Comisky Park. Id. at 583.

The court also addressed the defendant's arguments that $\S 245(\mathrm{~b})(2)(\mathrm{B})$ was unconstitutional. For the same reason, the court's analysis contributed little to the question of whether $\S 245(\mathrm{~b})(2)$ is unconstitutional. Moreover, $\$ 245(\mathrm{~b})(2)$ may merit more scrutiny than $\S 241$ because it requires a showing of racial animus. See 18 U.S.C. $\S 245(b)$. 
specific intent to violate section 241. Moreover, should other courts follow the McDermott court's analysis, prosecutors and courts will be burdened by having to respond to free speech defenses in section 241 cases arising from hate crimes. Despite ample evidence of threateming conduct in inany of these cases, they frequently involve some form of expressive conduct, thereby implicating the defendants' free speech rights. ${ }^{233}$ Courts should not allow defendants in such cases to attempt to base a First Amendment defense on the fact that part of their actions constituted expressive conduct. To do so would pervert the basic law of conspiracy.

\section{CONCLUSION}

Federal prosecutors have identified in section 241 a convenient tool to prosecute hate crimes. After the Supreme Court's ruling in R.A.V. v. City of St. $\mathrm{Paul}^{234}$ declaring content-based hate crime ordinances unconstitutional, section 241 offers an alternative avenue of prosecution when state and local prosecutors are unable to act. Courts should ensure, however, that U.S. attorneys, in their eagerness to prosecute hate crimes, do not misuse section 241 to punish opprobrious but otherwise protected conduct.

This Note has argued that section 241 does not pose any First Amendinent concerns. Courts can avoid the potential conflict between the two by properly construing the statute's mens rea requireinent and carefully defining the predicate right. When First Amendinent concerns are raised with regard to section 241, courts should scrutinize the constitutionahty of the underlying statute that provides the basis for the section 241 conviction. If the mens rea requirement has been satisfied and First Amendinent concerns persist, it is likely that the zone of interest created by the predicate right implicates speech activity. ${ }^{235}$

233. See, e.g., supra note 145 (noting cases involving unprotected acts of cross burning).

234. 112 S. Ct. 2538 (1992).

235. This analysis does not suggest that statutes such as 42 U.S.C. $\S 3631(a)$ and 42 U.S.C. $\S 2000 \mathrm{a}(\mathrm{a})$ infringe on free speech rights. Indeed, one court has ruled that $\S$ 3631(a) is not unconstitutionally overbroad. See United States v. Gilbert, 813 F.2d 1523, 1530 (9th Cir.), cert. denied, 484 U.S. 860 (1987). Rather, the author is suggesting that because $\S 241$ is a crininal statute that is triggered by conspiracies against other rights, it cannot be employed when a court has fonnd the underlying statute constitutionally impaired. 
Section 241 , like section 242 , has had a controversial history and has withstood constitutional challenges on vagueness and federalism grounds. ${ }^{236}$ Commentators have suggested, perhaps wisely, that Congress should replace these old civil rights laws with more precise laws. ${ }^{237}$ Nevertheless, until Congress sees fit to do so, courts and prosecutors must effectively utilize these civil rights enforcement statutes to combat the continuing violations of civil rights by private actors. Section 241 can serve them better if they slield it from unnecessary constitutional challenges. Through proper apphication of the statute's mens rea element, the courts, at least, can rescue section 241 from further unwarranted First Amendment challenges.

236. See supra notes $22,44-48$ and accompanying text.

237. See, e.g., Malone, supra note 18, at 222. 